\title{
Aproximación al pensamiento de Octavio paz
}

\author{
- Luis Armando González \\ "Mi ideal, inalcanzable, ha sido ser \\ un semejante ante mis semejantes"
}

Octavio PAz

\section{RESUMEN}

El propósito de este ensayo es presentar una visión de conjunto del pensamiento de Octavio Paz. El autor hace un recorrido sobre las ideas estéticas, políticas y filosóficas del intelectual mexicano con la intención expresa de motivar el acercamiento hacia uno de los intelectuales latinoamericanos más brillantes y agudos del siglo XX. Para el autor del ensayo, Paz fue un pensador latinoamericano en un sentido en el que deberían serlo aquellos que, asumiendo en toda su contundencia la herencia y el carácter occidental europeo de América Latina, quieren entender el modo cómo los latinoamericanos han ido fraguando su particular modo de ser occidentales.

\section{Introducción}

Octavio Paz es una de las figuras intelectuales más importantes del siglo XX en América Latina. Latinoamericano con vocación universal, supo moverse con crealividad en ámbitos del saber tan divergentes como la poética, siendo él mismo un poeta, la teoría y la crítica literaria, la historia de las ideas políticas, la filosofía y el pensamiento oriental. 
Sin renunciar a buscar lo más propio de América Latina, en las ideas, el arte, la política y la cultura, Paz supo sortear con solvencia los peligros a los que puede conducir una búsqueda de la identidad latinoamericana al margen de la herencia y la tradición occidental. Fue particularmente lúcida su consideración de América Latina como una "excentricidad" de Europa, es decir, como una parte de Europa, pero situada en sus bordes, fuera de su centro de irradiación cultural, social, económica y política.

Sin resentimientos de ninguna especie, Paz reconoció que América Latina es parte de Occidente, con todos los pros y contras que de ello se ha seguido: los pros, el aprendizaje de un idioma (y de una visión de mundo) que ha permitido el diálogo con tradiciones culturales que se remontan a los griegos; los contra, la asimilación de formas de ver el mundo - la política, la sociedad, la economíaque no tenían sustento en la realidad latinoamericana. América Latina se entreteje de esos pros y contra; sus posibilidades de desarrollo, las frustraciones colectivas y los sueños truncados de sus pueblos han estado marcados por su particular inserción en Occidente.

Paz fue un pensador latinoamericano, sí, pero no a la manera de aquellos intelectuales que se esfuerzan aun ahora por encontrar lo "propio", lo "incontaminado" por el occidente europeo en América Latina. Fue un pensador latinoamericano, primero, porque era mexicano; y, segundo, porque se interesó en comprender el lugar propio de América Latina en el escenario de la historia mundial, particularmente en el contexto de la historia occidental. "Por la historia, la lengua y la cultura pertenecemos - escribió- a Occidente, no a ese nebuloso Tercer Mundo del que hablan nuestros demagogos. Somos un extremo de Occidente —un extremo excéntrico, pobre y disonante"'.

Siendo razonables, esas son las dos condiciones básicas para que un intelectual latinoamericano pueda ser considerado como tal; lo demás —que piense exclusivamente problemas latinoamericanos, que recurra a categorías de pensamiento autóctonas — prehispánicas-, que sólo tenga como interlocutores a otros intelectuales latinoamericanos, que nunca salga de la región a cursar estudios o a participar en congresos-, es, o ingenuidad, o provincianismo.

Paz no fue ni ingenuo ni provinciano, sino sumamente crílico y con una vocación universal. Su proyección intelectual fue la de un mexicano que entendió los problemas de su país y de América Latina en una perspectiva más amplia. Su obra expresa sus preocupaciones personales; en ella se abordan temas locales (mexicalnos y latinoamericanos ${ }^{2}$ ), pero también temas de un alcance más universal, como

1. O. Paz, "Literatura y crítica". En Fundación y disidencia. Dominio hispánico. Ohras completas (III). México, FCE, 1994, p. 61

2. En cste campo, uno de sus cscritos más logrados cs El laherinto de la soledad (México, FCE, 1994) en el que aborda el espinoso tema de la identidad del mexicano. 
las religiones y el arte orientales, la cultura occidental y el totalitarismo, sólo para mencionar algunos de los problemas que lo ocuparon a lo largo de su vida.

Fue un pensador latinoamericano en un sentido en el que deberían serlo todos los que, asumiendo en toda su contundencia la herencia y el carácter occidental europeo de América Latina, quieren entender el modo cómo los latinoamericanos han ido fraguando su particular modo de ser occidentales, pero también cómo los hombres de todos los tiempos han ido enfrentando problemas que escapan a los particularismos locales, pues son consustanciales a la condición humana.

Octavio Paz escribió en una oportunidad lo siguiente: “los grandes libros - quiero decir, los libros necesarios- son aquellos que logran responder a las preguntas que, oscuramente y sin formularlas del todo, se hace el resto de los hombres". A lo largo de los 14 tomos que conforman sus Obras Completas, Paz aborda con lucidez y profundidad muchas de esas preguntas que, oscuramente y sin formularlas del todo, se hace el resto de los hombres.

Aproximarse, con la ayuda de Paz, a esas preguntas no sólo es estimulante desde un punto de vista intelectual, sino enriquecedor desde un punto de vista vital. Eso es lo que hemos pretendido al comenzar la redacción de estas páginas. Se trata de una aproximación a la obra de uno de los intelectuales latinoamericanos más agudos y brillantes del siglo XX. Se trata, a la vez que de un modesto homenaje a su trayectoria, de una invitación — para todos aquellos que todavía no lo han hecho- a la lectura de sus libros que son, nunca mejor dicho, unos libros necesarios. Estas páginas quieren ser un ensayo de aproximación al pensamiento de Octavio Paz, es decir, una invitación a su lectura. Nos hacemos cargo, para ello, de la noción de "ensayo" que ofrece Fernando Mires en su Teoría política del nuevo capitalismo". "Cada ensayo - dice Mires- es un intento de comunicación; un llamado telefónico a los demás; un e-mail dirigido al destino. El ensayo ensaya la realidad sobre la que ha sido escrito. $Y$ no tiene más poder que el de lo efímero. Quien quisiera escribir un ensayo y busque la eternidad, ha fracasado antes de comenzar a escribir. El ensayo, al igual que las luciérnagas, vive en tiempo presente. Consume lo inmediato cuando su sangre aún es tibia, y formula veredictos que no tienen más duración que la que puedan tener"4.

\section{Datos biográficos}

Octavio Paz nació en 1914, en la Ciudad de México. Siendo muy joven participó en el II Congreso Internacional de Escritores Antifascistas, celebrado en Valencia, en 1937, en el marco de la guerra civil española. Un año después, colaboró en la fundación de la revista Taller, desde la cual fue impulsada una nueva generación de escritores mexicanos, entre quienes sobresalen Enrique

3. F. Mires, Teoria política del nuevo capitalismo. Caracas, Nueva Sociedad, 200()

4. Ihid., p. 8 
González Martínez, Carlos Pellicer, Alberto Quintero Alvarez, Manuel Lerín, Efraín Huerta y Enrique Herrero. En 1943 se trasladó a Estados Unidos, donde descubrió y se sumergió en la poesía del modernismo angloamericano. En esta época, Paz elabora su teoría de la "conciliación de los contrarios", según la cual las dicotomías poder-contemplación, magia-religión, soledad-comunión, inocencia-conciencia, se resuelven en la búsqueda de la experiencia del absoluto. En 1945 ingresa en el cuerpo diplomático de su país y fue destinado a París, en donde se vinculó estrechamente al movimiento surrealista, una de cuyas principales figuras, André Breton, influyó decisivamente en su pensamiento. La influencia de Breton llevó a Paz a decir cosas como estas: "el verdadero amor, el amor libre y liberador, es siempre exclusivo e impide toda caída en la infidelidad". En 1962, Paz fue nombrado embajador en la India, lo cual dejó una huella permanente - vital e intelectual - en el mexicano. Tres obras recogen directamente la experiencia de Paz en la India: El mono gramático, Ladera este y Vislumbres de la India. En 1968 dimitió de su cargo en el servicio diplomático, como medida de protesta por la masacre de los estudiantes en Tlatelolco. Desde entonces, se dedicó a su obra, así como a la colaboración en dos importantes revistas fundadas por él: Plural (1971-1976) y Vuelta (a partir de 1976), revista esta última galardonada con el Premio Príncipe de Asturias, en 1993. Octavio Paz, por su parte, obtuvo en 1981 con el Premio Cervantes y en 1990 el Premio Nobel de Literalura. Paz transitó hacia la "otra orilla" — de la que no hay regreso- en 1998, precisamente cuando terminaba la revisión del conjunto de sus escritos, recogidos en la cdición de sus Obias completas a cargo del Fondo de Cultura Económica.

\section{Poeta y crítico literario}

A Octavio Paz se le conoce, fundamentalmente, como poeta y como crítico literario. Ello no es casual, pues en ambos campos el aporte de Paz ha sido significativo. Por lo primero, el mexicano hizo su poesía en diálogo y ruptura con la tradición poética de Occidente y de Oriente, así como con sus contemporáneos. Por lo segundo, Paz examinó con perspicacia y lucidez tanto el talante crítico de la modernidad, como el modo en el que ese talante se expresa en la litcratura. Eso es lo que veremos a continuación.

\subsection{Poesía: diálogo y ruptura}

Como poeta, supo insertarse en lo mejor de las tradiciones poéticas de Occidentc - los clásicos de la poesía española, el modernismo y el surrealismo- no para repetirlas, sino para aprender de ellas, asimilar lo mejor que podían ofrecerlc y continuarlas mediante su transformación. En este punto, Paz fue siempre consciente que un poeta nunca partía de cero - tenía que dialogar con quienes lo precedieron, aprender de ellos-, pero que no podía limitarse a repetirlos mecánicamente, sino que debía recrearlos, a partir de su propia problemática vital y social; al recrearlos, los continuaba y los negaba. 
Para explicar su propio punto de vista al respecto, Paz se refirió en alguna ocasión a la analogía de la catálisis, utilizada por T.S. Eliot en su ensayo "La tradición y el talento individual”, para explicar la creación poética. Manuel Ulacia nos hace saber quc, según Eliot, la mezcla de dos gases en presencia de un lilamento de platino para producir ácido sulfúrico es similar al fenómeno mecliante cl cual se gesta cl poema en la mente del poeta'.

El texlo de Eliot dice lo siguiente: "esta combinación sólo tiene lugar en presencia del platino; sin embargo, el ácido recién formado no contiene rastros (lc platino, y el platino mismo está visiblemente intacto; ha permanecido inerte, neutral, inalterado. La mente del poeta es el trozo de platino. Puede obrar en parte o exclusivamente sobre la experiencia del hombre mismo; pero cuando más perfecto es el artista, más completamente separados estarán en él el hombre cue sufre y la mente que crea; con mas perfección asimilará y trasmutará la mente las pasiones que son su material"h.

"El poeta mexicano — señala Manuel Ulacia - asumirá las tradiciones con las que dialoga de esa lorma, es decir, críticamente. Pero la asunción de las tradiciones con las que dialoga operan de la misma manera que los gases a los que alude Eliot en su ensayo. Parece como si estas desaparecieran ante la presencia cle la mente del poeta, por la capacidad que tiene éste de lograr la catálisis. Este lenómeno ocurrirá... en toda la obra de Paz. En ella parece que lo único que queda es la voz inconfudible del poeta"?.

Esa voz es palabra poética, poema único e inconfundible, poesía: "el poema es mediación: por gracia suya, el tiempo original, padre de los tiempos, encarna en un instante. La sucesión se convierte en instante puro, manantial que se alimenta a sí mismo y trasmuta al hombre. La lectura del poema ostenta una gran semejanza con la creación poética. El poeta crea imágenes, poemas; y el poema hace del lector imagen, poesía"k.

Es en este sentido que para el mexicano cada poema es único: "es la revelación de nuestra condición y, por eso mismo, la creación del hombre por la imagen. La revelación es creación. El lenguaje poético revela la condición paradójica del hombre, su 'otredad', y así lo lleva a realizar lo que es... "’.

5. M. Ulacia, El árbol milenario. Un recorrido por la obra de Octavio Paz. Barcelona, Galaxia Gutenberg-Círculo de Lectores, 1999, pp. 104-105

6. T.S. Eliot, "La tradición y el talento individual". Citado por M. Ulacia en Op. Cit., p. 105

7. Ibid.. p. 105

8. O. Paz, "El arco y la lira". En La casa de la presencia. Poesía e historia. Obras completas (1). México, FCE, 1994, p. 51

9. Ibid.. pp. 165-166 


\section{La poesía nos abre la posibilidad \\ de ser que entraña todo nacer; recrea al hombre \\ y lo hace asumir su condición verdadera, \\ que no es la disyuntiva: vida o muerte, sino una totalidad: \\ vida y muerte en un solo instante \\ de incandescencia}

De aquí que aunque el poeta se alimenta de estilos — sin estilos no habría pocmas-. "Ios poemas permanecen y cada uno de ellos constituye una unidad autosuliciente, un cjemplar aislado, que no se repetirá jamás"'l". Para llegar a la creación de esa unidad autosuficiente que es el poema, el poeta, su creador, dialoga con la tradición poética, pero no la repite. sino que "utiliza, adapta o imita el fondo común de su época —esto es, el estilo de su tiempo- pero trasmuta todos esos materiales y realiza una obra única"".

A lo largo de su vida, Paz mantuvo un diálogo permanente con los más importantes poetas que le precedieron, así con poetas contemporáneos suyos. De ese diálogo, nacicron verdaderas joyas poéticas que ya son parte —al insertarse con voz propia dentro de ella- cle la poesía universal. Sólo como ejemplo, se pueden leer los siguientes poemas, correspondientes a cuatro épocas distintas en la hiogralía intelectual del mexicano'?2:

1). Ibicl., p. 45

II. Ibid.

12. El primer poema. influenciado por la poesía de Pablo Neruda y el erotismo de D.H. Lawrence. cuando $\mathrm{Paz}$ daba sus primeros pasos fïrmes en la creación poética; el segundo. por su compromiso con la causa republicana durante la guerra civil española: el tercero. por los clásicos de la poesía española, concretamente por Francisco de Quevedo; y el cuarto. influenciado por la cultura oriental -específicamente el I Ching- y el surrealismo. M. Ulacia, en su obra citada, distingue cuatro diálogos intelectuales (y culturales) sostenidos por Octavio Paz a lo largo de su trayectoria vital: el primero, con los poetas de Contemporáneos, la Generación del 27 y el Siglo de Oro español; el segundo, con los poetas franceses y anglosajones. (Mallarmé, Bretón, Eliot. Pound, Rimbaud, William Carlos Williams, e.e. cummings, Apollinaire, Baudelaire); el tercero con la cultura oriental (pensamiento hindú, poesía japonesa); y el cuarto, con México y sus problemas políticos, sociales y económicos, a partir de los años 70. Cfr. M. Ulacia, El árbol milenario..., pp. 391.401 


\section{I}

Toca tu desnudez en la del agua, Desnúdate de ti, llueve en ti misma, Mira tus piernas como dos arroyos, Mira tu cuerpo como un largo río, Son dos islas gemelas tus dos pechos, En la noche tu sexo es una estrella, Alba, luz rosa entre dos mundos

Mar profundo que duerme entre dos ciegos, mares.

Mira el poder del mundo:

Reconócete al reconocerme.

\section{II}

Como pájaros ciegos, prisioneros, como temblantes alas detenidas o cánticos sujetos, suben amargamente hasta la luz aguda de los ojos y el desgarrado gesto de la hoca, los latidos febriles de la sangre, petrificada e irrevocable: no pasarán.
III

Sombras del día blanco

Contra mis ojos. Yo no veo

Nada sino lo blanco:

La hora en blanco, el alma

Desatada del ansia y de la hora.

\section{IV}

Entro por tus ojos

sales por mi hoca

duermes en mi sangre

despierto en tu frente.

\subsection{Crítica, modernidad y literatura}

Como crítico literario, Paz centró buena parte de sus esfuerzos intelectuales en entender, primero, la importancia de la crítica en la modernidad; segundo, en analizar la forma que adquiere la crítica en las creaciones literarias modernas ${ }^{13}$,

13. Y cn el arte en gencral, como lo ponen de manificsto los tomos 6 y 7 de sus Obras completas: Los privilegios de la vista I. Arte moderno universal y Los privilegios de la vista II. Arte de México. Concretamentc, cl análisis de la obra Gran vidrio de Marcel Duchamp lleva a Paz a decir lo siguiente: "no cs lícilo llamar al Gran vidrio el Mito de la Crítica. Es un cuadro que hace pensar en ciertas obras que anuncian y revelan la ambigüedad del mundo moderno, su oscilación cntre el mito y la crítica. Pienso en la epopeya burlcsca de Ariosto y en el Quijote, que cs una novela ćpica y una crítica de la épica. Con estas creaciones nace la ironía moderna; con Duchamp y otros poetas del siglo XX, como Joyce, la ironía se vuelve contra sí misma. El círculo se cierra: fin de una ćpoca y comienzo de otra. El Gran vidrio cs la frontcra entre uno y otro mundo, el de la 'modernidad' que agoniza y el nuevo que comienza y que aún no tiene forma". O. Paz, "El castillo de la purcza". En Los privilegios de la vista I. Arte moderno universal. Obras completas (VI). Mćxico, FCE, 1991, p.180. 
Ianto en Europa como en América Latina ${ }^{14}$; y, tercero, en ejercer él mismo la tarea de crítico literario.

Sobre lo primero, Paz insistió en que uno de los rasgos centrales de la modernidad, tal como ésta se ha desplegado en el Occidente europeo, consiste en la capacidad de cuestionarse a sí misma en sus fundamentos más profundos. Esta capacidad de autocuestionamiento — una vez que se cuestionaron todas las verdades premodernas - se llama crítica. ¿Qué entiende por "crítica" el intelectual mexicano? Para él, en un primer momento, la crítica es el "ácido" que disuelve las oposiciones entre "lo antiguo y lo contemporáneo y entre lo distante y lo próximo"'s. Como ácido, la crítica no es fría y distante, sino comprometida y apasionada: se trata de una pasión crítica.

La modernidad - la época histórica que se inicia con el derrumbe del orden medieval- está atravesada por esa pasión crítica. Ahora bien, ¿qué es la modernidad y cuál es el significado de la crítica (la pasión crítica) dentro de ella? Vayamos por pasos: primero, veamos qué entiende Paz por "modernidad"; en segundo lugar, detengámonos en el problema de la "pasión crítica".

Para comenzar, el mexicano se refiere al concepto de "modernidad". Y señala lo siguiente: "la modernidad es un concepto exclusivamente occidental y que no aparece en ninguna otra civilización. La razón es simple: todas la otras civilizaciones postulan imágenes y arquetipos temporales de los que es imposible deducir, inclusive como negación, nuestra idea del tiempo... Es claro que la idea de modernidad sólo podía nacer dentro de esta concepción de un tiempo sucesivo e irreversible; es claro que sólo podía nacer como una crítica de la eternidad cristiana"'k.

Una vez precisado el carácter occidental del concepto, Paz aborda el problema de los comienzos de la época moderna. "Algunos piensan — dice- que se inició en el Renacimiento, la Reforma y el Descubrimiento de América; otros suponen que comenzó con el nacimiento de los Estados nacionales, la institución de la banca, el nacimiento del capitalismo mercantil y la aparición de la burguesía; unos pocos subrayan que lo decisivo fue la revolución científica y filosófica del siglo XVI, sin la cual no tendríamos técnica ni industria. Todas estas opiniones son admisibles. Aisladas son insuficientes; unidas ofrecen una explicación coherente"17.

14. En efecto, un amplio apartado de la obra de Octavio Paz está dedicado al problema del arte en América Latina, especialmente de la literatura moderna. Paz no dudó de la modernidad de la literatura hispanoamericana, de la cual llegó a decir que "no es solamente la expresión de nuestra realidad ni la invención de otra realidad: también es una pregunta sobre la realidad de esas realidades". O. Paz, "Literatura y crítica". En Fundación y disidencia..., p. 61

15. O. Paz, "Los hijos del limo". En La casa de la presencia. Poesia e historia. Obras completas (I). México, FCE, 1994, pp. 335-336

16. Ibid. p. 352

17. O. Paz, "La otra voz. Poesía y fin de siglo". En La casa de la presencia..., p. 501 
Así pues, en el advenimiento de la modernidad se ven imbricados múltiples fenómenos, culturales, económicos, políticos y sociales, cuya consideración unitaria es necesaria para comprender la época a cuya gestación contribuyen. Sin embargo, en la perspectiva de Paz, la modernidad comienza con la crítica: "crítica de la religión, la filosofía, la moral, el derecho, la economía y la política. La crítica es su rasgo distintivo, su señal de nacimiento. Todo lo que ha sido la Edad Moderna ha sido obra de la crítica, entendida ésta como un método de investigación, creación y acción"|k.

Pero no sólo eso, la crítica es también una pasión; según Paz es una "pasión crítica": "amor inmoderado, pasional, por la crítica y sus precisos mecanismos de deconstrucción, pero también crítica enamorada de su objeto, crítica apasionada por aquello mismo que niega. Enamorada de sí misma y siempre en guerra consigo misma, no afirma nada permanente ni se funda en ningún principio: la negación de todos los principios, el cambio perpetuo, en su principio. Una crítica así no puede sino culminar en un amor pasional por la manifestación más pura e inmediata del cambio: el ahora"1".

La modernidad está, desde sus orígenes, en guerra consigo misma, negando sus principios, en cambio perpetuo ${ }^{20}$. "Desde su nacimiento — señala Paz - la moderniclad es una pasión crítica y así es una doble negación, como crítica y como pasión, tanto de las geometrías clásicas como de los laberintos barrocos. Pasión vertiginosa, pues culmina en la negación de sí misma: la modernidad es una suerte de autodestrucción creadora... Lo que distingue a nuestra modernidad de las otras épocas no es la celebración de lo nuevo y sorprendente, aunque también cso cuentc, sino ser una ruptura: crítica del pasado inmediato, interrupción de la continuidad"2!.

Esa pasión crítica se expresa con particular luerza en la creación artística, pues el "arte moderno no sólo es el hijo de la edad crítica, sino que también es cl crítico de sí mismo"’?2. Es decir, en el arte moderno no sólo manifiesta el talante crítico de la modernidad, sino que él mismo se somete a la dinámica corrosiva de aquélla; el arte moderno es un arte de "ruptura", un arte en búsqueda permanente de lo nuevo, lo sorpresivo y lo distinto, no importa de dónde procedan — del pasado o de otras civilizaciones contemporáneas-, sino su conuribución al cambio, al rechazo de lo establecido.

18. Ibicl... p. $501-502$

19. Ibicl.. p. 336

2). Eso llevó a Paz a decir. en otro escrito, que la modernidad es "apetito de cambio" y "conciencia de ese cambio". Ver O. Paz. "Presencia y presente: Baudelaire crítico de arte". En Los privilegios de la vista I. Arte moderno universal. Obras completas (VI). México. FCE, 1994, p. 48

21. O. Paz, "La otra voz. Poesía y fin de siglo...". pp. 334-335

22. O. Paz. "Los hijos del limo". En La casa de la presencia... pp. 335 
"Lo nuevo nos seduce no por nuevo sino por distinto; y lo distinto es la negación, el cuchillo que parte en dos al tiempo: antes y ahora. Lo viejo de milenios puede acceder a la modemidad: basta con que se presente como una negación de la tradición y que nos proponga otra. Ungido por los mismos poderes polémicos que lo nuevo, lo antiquísimo no es un pasado: es un comienzo. La pasión contradictoria lo resucita, lo anima y lo convierte en nuestro contemporáneo"2.?.

En la literatura moderna se hizo presente esta ansia crítica de la modernidad; Paz dedicó buena parte de sus esfuerzos intelectuales al examen de ese rasgo constitutivo de la literatura moderna. Para él, la creación artística en la que mejor se expresa la modernidad es en la novela; su momento fundacional, Don Quijote de la Mancha, de Miguel de Cervantes.

Desde Cervantes, la novela se constituye sobre un héroe que duda no sólo de sí mismo, sino de la realidad que lo sustenta. Es cierto, en la novela hay realismo, pero su realismo "es una crítica de la realidad y hasta la sospecha de que sea tan irreal como los sueños y las fantasías de Don Quijote"24. Con Cervantes, pues, aparece esa dimensión crítica — de sospecha - sobre lo real de la realidad que va a ser la característica de la novela.

Pero también con él aparecen otros dos rasgos constitutivos de la novela: el humor - que "vuelve ambiguo lo que toca"- y la ironía — que inserta la subjetividad en el orden de la objetividad. "En la obra de Cervantes hay una continua comunicación entre realidad y fantasía, locura y sentido común. La realidad castellana, con su sola presencia hace de Don Quijote un esperpento, un personaje irreal; pero de pronto Sancho duda y no sabe ya si Aldonza es Dulcinea o la labradora que él conoce, si Clavileño es un corcel o un pedazo de madera. La realidad castellana es la que ahora vacila y parece inexistente" 25.

Entre Don Quijote y su realidad —señala Paz - se establece una "desarmonía". Esa desarmonía resuelve mediante la fusión de ambos términos: esa fusión es el humor y la ironía, "la gran invención del espíritu moderno. Son el equivalente del conflicto trágico y por esos nuestras grandes novelas resisten la cercanía del teatro griego. La fusión de la ironía es una síntesis provisional, que impide todo desenlace efectivo... Por obra del humor, Cervantes es el Homero de la sociedad moderna"-3".

El humor y la ironía desembocan en la crítica de la sociedad, rasgo constitutivo de la novela. "Épica de una sociedad que se funda en la crítica, la novela es un juicio implícito sobre esa misma sociedad... es una pregunta acerca de la

23. Ibid., p. 395

24. O. Paz, "El arco y la lira". En La casa de la presencia..., p. 223

25. Ibid. p. 224

26. Ibid., pp. 224-225. 
realidad de la realidad"'-27. Es una pregunta que nunca encuentra una respuesta definitiva; es una pregunta que, al satisfacerse con ninguna respuesta, contribuye a la crisis de los fundamentos que sacude a la sociedad moderna.

La novela es uno de los corrosivos de la modernidad. El movimiento se inició con Cervantes, a quien siguieron otras grandes figuras de la creación literaria moderna: Balzac, en cuya obra "la sociedad se condena a sí misma y a sus principios"; Proust, quien "repite el gesto y vuelve a condenar a la sociedad a la que había pretendido revivir y contar"; Kafka, para quien el mundo es una "Comedia infernal"; Tolstoi, Dostoievski, Swift y Henry James, para quienes "los triunfos de la razón son también sus derrotas"; Flaubert, en quien "la prosa se niega como prosa"; Joyce "que hace recobrar a la palabra su autonomía para que rompa el hilo del pensamiento discursivo"-2k.

En resumen, desde Cervantes hasta los novelistas contemporáneos, la novela ha sido expresión de la crítica que la modernidad hace permanentemente de sí misma. Pero no sólo eso: la crítica de la novela no es sólo hacia la sociedad, sino también hacia sí misma. "La novela es una épica que se vuelve contra sí misma y que se niega de una manera triple: como lenguaje poético, mordido por la prosa; como creación de héroes y mundos, a los que el humor y el análisis vuelven ambiguos; y como canto, pues aquello que su palabra tiende a consagrar y exaltar se convierte en objeto de análisis y a fin de cuentas en condena sin apelación"’"'s.

La gran tendencia de la novela moderna, después de haber abandonado el lenguaje de la poesía y acercarse a la prosa, es la de un regreso a la poesía. Así, en la actualidad, "la lucha entre prosa y poesía, consagración y análisis, canto y crítica, latente desde el nacimiento de la sociedad moderna, se resuelve por el triunfo de la poesía" ${ }^{\text {?o. }}$.

Para Paz, ese "triunfo de la poesía" tiene un significado mayor que el de un mero volver a empezar. Es una señal de "extinción" de la edad moderna, es decir, del ocaso de la idea de futuro como tierra prometida. El hombre contemporáneo ve quebrarse esa idea y sus ejes de referencia básicos: el tiempo lineal, el cambio y el progreso. Asistimos al "fin de la modernidad y de su visión de tiempo como un proceso unilineal, identificado con el movimiento ascendente de la historia. Asistimos al crepúsculo de la religión del futuro, sol del progreso. "vivimos el fín de la modernidad y el comienzo de otro tiempo":?!

\footnotetext{
27. Ibicl.

28. Ibicl.. pp. 224-227

29. Ibicl. P. 225

30. Ibicl., p. 227

31. "Respuestas nuevas a preguntas viejas. (Entrevista con Juan Cruz)". En Icleas y costumbres l..., p. 495
} 
¿Se está arribando a una era postmoderna? Paz vislumbra algo más radical que eso. "Llamarse postmoderno es una manera más bien ingenua de decir que somos muy modernos. Ahora bien, lo que está en entredicho es la concepción lineal del tiempo y su identificación con la crítica, el cambio y el progreso -el tiempo abierto hacia el futuro como tierra prometida. Llamarse postmoderno es seguir siendo prisionero del tiempo sucesivo, lineal"??

Precisamente, lo que está en crisis es ese tiempo sucesivo, lineal. Y la literatura resiente esa situación de crisis a la que ella misma ha contribuido a crear. La estética que alimentó a esta literatura - y en general al arte moderno- fue una "estética del cambio". "Hoy asistimos al crepúsculo de la estética del cambio. El arte y la literatura de este fin de siglo han perdido paulatinamente sus poderes de negación; desde hace años sus negaciones son repeticiones rituales, fórmulas sus rebeldías, ceremonias sus transgresiones. No es el fin del arte: es el fin de la idea de arte moderno. O sea, el fin de la estética fundada en el cambio y la ruptura".3?.

En la novela, el fin de esa estética se anuncia como una vuelta al lenguaje poético, en "el cual el presente se manifiesta en la presencia y la presencia es la conciliación de los tres tiempos. Poesía de la reconciliación: la imaginación encarnada en el ahora sin fechas" "74. De lo que se trata es de reivindicar el ahora, el tiempo presente, el instante, "tiempo de placer" y "tiempo de la muerte", "tiempo de los sentidos" y tiempo del más allá"3. que la poesía ha sido siempre la "visión de la presencia del ahora encarnado"- es sólo un punto de partida, pues "los hombres tendrán muy pronto que edificar una Moral, una Política, una Erótica y una Poética del tiempo presente", porque en delinitiva "el presente es el fruto en el que la vida y la muerte se funden".36.

\section{Ideas políticas}

Desde muy temprano en su trayectoria intelectual, se interesó en la política tanto en al plano de la elaboración conceptual como en el plano del compromiso práctico. En esta segunda veta - la del hombre político- Paz recorrió un largo camino que fue desde una aceptación de la causa socialista hasta el rechazo a cualquier forma de totalitarismo y la aceptación crítica de la democracia.

Sus ideas políticas fueron cobrando forma al calor de las posturas que, ante los problemas de su tiempo, fue asumiendo a lo largo de su vida. La comprensión de aquellas es clave para entender el itinerario personal de Octavio Paz

32. O. Paz, "La otra voz...", p. 515

33. Ibicl.

34. Ibicl., p. 517

35. Ibid. P. 516

36. Ibid. 
como hombre político, porque al fin y al cabo, como intelectual que era, siempre se esforzó por ofrecer una elaboración teórica de sus opciones ciudadanas. Esa elaboración estuvo marcada por la crítica. "En materia política, nuestra crítica se desplegó en varias direcciones: el sistema político mexicano, fundado en un excesivo presidencialismo y en la hegemonía de un partido hechura del Estado; el sistema totalitario soviético con sus satélites y el chino con los suyos; las dictaduras, especialmente las de América Latina; la política de las democracias liberales de Occidente, en particular la de los Estados Unidos"17.

En ese ejercicio crítico, una serie de ideas políticas fueron adquiriendo consistencia propia, hasta convertirse en los ejes de la reflexión política emprendida por Octavio Paz. Entre las ideas políticas más importantes figuran las siguientes: democracia, capitalismo, revolución, socialismo, nacionalismo y fundamentalismo. Su examen nos permitirá hacernos cargo de lo que podríamos llamar la "filosofía política" de Octavio Paz.

\subsection{Democracia}

Ante todo, Octavio Paz reflexiona sobre el fundamento de la democracia, sobre su razón de ser. Para él, ese fundamento es "la creencia en la capacidad de los ciudadanos para decidir, con libertad y responsabilidad, sobre los asuntos públicos" "wx. La libertad y la responsabilidad de los ciudadanos son el requisito básico no sólo para enriquecer la discusión de los asuntos públicos, sino también para que aquéllos ejerzan y defiendan sus derechos políticos fundamentales.

Obviamente, cuando la libertad y la responsabilidad ciudadanas desfallecen, la democracia se ve fucrtemente socavada. Precisamente, algo de eso vislumbra Paz en las democracias modernas, en las cuales la política tiende a convertirse en una "rama de la industria del entretenimiento" y la libertad de expresión amenaza con convertirse en "un instrumento de domesticación intelectual, moral y política" ’".

La expresión más palpable de este desfallecimiento de la democracia moderná es la transiormación del debate público en "una ceremonia y un espectácuI0" "(1), así como la "masificación" de los ciudadanos, es decir, "el conlormismo, la vulgaridad de sus pasiones, la uniformidad de sus gustos, ideas y convicciones".ll. Scgún Paz, "la masificación (...) de los ciudadanos y la transformación (lel debate público en espectáculo son rasgos que degradan a las democracias modernas. Denunciar csos males es defender a la verdadera democracia" ${ }^{2}$.

37. O. Paz. "Itinerario". En Ideas y costumbres. La letra y el cetro I. Obras completas (IX). Mćxico. FCE, 1995. p. 51

38. Ihicl.,p. 61

39. Ihicl.. p. 62

40. Ibicl.

41. Ihid.

42. Ibid. 
Pcro la democracia no sólo se va acosada por la masificación y la transformación del debate público en espectáculo, sino por otra dolencia no menos incuuietante: el debilitamiento de la virtud —el "dominio sobre nosotros mismos"-, sin la cual, al no poder dominar nuestros apetitos, "estamos listos a ser dominados por el extraño" $"$.

De lo que se trata es de rescatar a la democracia de las garras de la masilicación, el espectáculo, los apetitos y las pasiones vulgares. Este es el paso previo para restituir a la democracia su carácter más propio: ser un "método de convivencia civilizada", que "no se propone cambiarnos ni llevarnos a ninguna parte; pide que cada uno sea capaz de convivir con su vecino, que la minoría aceptc la regla de la mayoría y que todos preserven y defiendan los derechos de los individuos. Como la democracia no es perfecta, la hemos completado con un sistema de equilibrio de poderes, imitado de los antiguos... El edificio está coronado por otro concepto: por encima de las mayorías, minorías e individuos, está el imperio de la ley, la misma para todos"44.

Obviamente, con la vigencia de la democracia los problemas del hombre no tcrminan. Y ello porque en su fortaleza como método de convivencia civilizada está su mayor debilidad: la democracia no está hecha para responder a las preguntas fundamentales del ser humano, es decir, a aquellas preguntas relativas a los orígenes, al destino, el 'sentido de la vida y de la muerte y al más allá.

La democracia no se identifica con ningún sistema de valores últimos, aunque tolera en su seno la pluralidad y la competencia entre valores diversos: en cso consiste el relativismo contemporáneo. "Tal vez una de las causas de la progresiva degradación de las sociedades democráticas —dice Paz- ha sido el tránsito del antiguo sistema de valores fundados en un absoluto, es decir, en una metahistoria, al relativismo contemporáneo... La democracia política y la convivencia civilizada entre los hombres exigen la tolerancia y la aceptación de valores e ideas distintos a los nuestros... Ni el Estado ni la sociedad en su conjunto pueden identificarse con esta o aquella creencia; todas ellas pertenecen al dominio de la conciencia personal. La democracia es una convivencia no sólo de personas sino cle ideas, religiones y filosofías"4.

Nada más ajeno a la democracia que los absolutos políticos, religiosos o lïlosólicos. Nada más propio de ella que ese vacío dejado por la ausencia de absolutos en su libra más esencial. Esto hace que la democracia, al carecer de centro y dirección, conduzca a la pérdida de una virtud fundamental para la convivencia humana: la "facultad de venerar", que es la "única que puede abrirnos las puertas a la fraternidad con los hombres y con la naturaleza. Sin fraterni-

43. Ibiel.

44. Ibicl., p. 59

45. Ibicl., p. 58

\section{2}


dad la democracia se extravía en el nihilismo de la relatividad, antesala de la vida anónima de las sociedades modernas, trampa de la nada"4h.

Es cierto, la democracia descansa en la libertad, tanto en la cslera del pensamicnto y las opciones individuales como en la estera económica. La primera no sólo supone una limitación del poder estatal, sino que conduce al ocaso de los absolutos y al surgimiento cle un nihilismo exacerbado. La libertad. en este punto. liene un clecto doble: el primero benélico, en tanto que ha permitido "limitar el poder del Estado. prevenir los abusos gubernamentales y ascgurar la libertad general: el scgundo, neláslo, pues ha llevado a una "sobrevaloración del individualismo" $"$ ?

La segunda, por obra y gracia del predominio absoluto del mercado, lleva a la degradación del medio ambiente y al egoísmo y a la indiferencia ante los otros. ante los marginados por el mercado. Así pues, "la democracia no está amenazada por ningún enemigo externo sino por sus males íntimos. Venció al comunismo pero no ha podido vencerse a sí misma. Sus males son el resultado de la contradicción que la habita desde su nacimiento: la oposición entre libertad y lraternidad. A csta dualidad en el dominio social corresponde, en la estera de las ideas y las creencias, la oposición entre lo rclativo y lo absoluto"sx.

\subsection{Capitalismo}

Para Octavio Paz. la discusión sobre la democracia cs inseparable de la discusión sobre cl capitalismo. El capitalismo, dicho sin más, es un sistema cconómico regulado por el mecanismo cle mercado. Su linalidad lundamental estriba en generar riquezal a partir de una producción y de un consumo que no se detienen antc nada: ni ante la naturaleza ni ante la saturación cle los consumidores. Paz caracteriza a las sociedades que articulan su sistema económico en torno al mercado como "sociedades liberales capitalistas", cuyo mayor mérito estriba en su elicacia, tal como lo demuestra su éxito sobre el modelo de intervención estatal implantado en la antigua ex URSS, cl cual a la larga no resislió la competencia con el modelo de libre mercado. "El mercudo libre ha mostrado que cs más elical\%, cso es todo. Las consecuencias de la estatización de la economía están a la vista: baja procluctividad, estancamiento, mal uso y dilapidación de los recursos humanos y naturales, obras laraónicas (pero sin la belleza de los egipcios), cscase\% generalizada, scrvidumbre de los trabajadores y un régimen de privilegios paral la burocracia"4t".

46. Ibicl., p. 65

47. O. Paz. "Democracia c imperio". En Ideas y costumbres l... p. 120)

48. O. Paz. "La democracia: lo absoluto y lo rclativo". En Ideas y costumbres I.... p. 489

49. O. Par. "Ilinerario". En Ideas y costumbres.... p. 55 
Ahora bien, la utilidad del mercado llega hasta donde llega su eficiencia y no más allí. Es decir, el mercado no busca responder a los problemas de pobreza, injusticia y clesigualdad que abaten a la mayor parte de la población en el mundo, los cuales en gran medida son provocados por el imperio de su lógica productivista y depredadora. En este punto, la crítica de Paz al mercado es particularmentc dura. Entre otros aspectos, el mexicano señala los siguientes ${ }^{40}$ :

a) "cl mercado es un mecanismo que crea, simultáneamente, zonas de abundancia y de pobreza. Con la misma elïciencia reparte bienes de consumo y la miseria";

b) "a la injusticia y la desigualdad hay que añadir la inestabilidad. Las sociedades capitalistas sufren crisis periódicas, desastres financieros, quiebras industriales. altas y bajas de sus productos y sus precios, cambios repentinos de fortuna entre los propietarios, desempleo crónico entre los trabajadores";

c) "el mercado es el promotor de cambios y las innovaciones técnicas; también es el rey del despillarro. Fabrica miles de objetos, todos de poca duración y cle baja calidad... Nos condena a desechar lo que compramos ayer y, por la boca ubicua de la publicidad, nos intoxica con la droga infernal de la novedad. Idolatría del siglo XX: la adoración de las cosas nuevas que duran lo que dura un parpadeo".

(l) "el mercado no se detiene nunca y cubre la tierra con gigantescas pirámides de basura y desperdicios; envenena los ríos y los lagos; vuclve desiertos las selvas; saquea las cimas de los montes y las entrañas del planeta; corrompe el aire, la tierra y el agua; amenaza la vida de los animales y de la de los animales y la de las plantas";

e) "el mercado no es una ley natural ni divina; es un mecanismo inventado por los hombres. Como todos los mecanismos es ciego: no sabe a dónde va, su misión es girar sin fïn”.

Así pues, "cl mercado es un mecanismo eficaz, pero, como todos los mecanismos, no tiene conciencia y tampoco misericordia. Hay que encontrar la manera de insertarlo en la sociedad para que sea la expresión del pacto social y un instrumento de justicia y equidad. Las sociedades democráticas desarrolladas han alcanzado una prosperidad envidiable; asimismo, son islas de abundancia en un océano de miseria universal. El tema del mercado tiene una relación muy estrecha con el deterioro del medio ambiente. La contaminación no sólo infesta al aire a los bosques, sino a las almas. Una sociedad poseída por el frenesí de producir más para consumir más tiende a convertir a las ideas, los sentimientos, el arte, el amor, la amistad y las personas mismas en objetos de consumo. Todo se vuelve cosa que se compra, se usa y se tira al basurero. Ninguna sociedad

50. Hid.. p. 56 
había producido tantos deshechos como la nuestra. Desechos materiales y morales".5!.

El mercado, en suma, urge de correctivos que moderen el impacto de la perversidad que lo atraviesa. Esos correctivos deben provenir de la democracia, la cual debe desbordar los límites propiamente políticos y trasladarse también a la esfera económica. "Concibo al mercado como una democracia. Así como la democracia política está regulada por la división de poderes, el mercado debe ser regulado por los empresarios, los obreros, los consumidores y el Estado" $\$ 2$. Pero no sólo eso: también el mercado debe ser regulado desde fuera por un marco de valores - por un humus cultural - fundado en lo mejor de la herencia espiritual cristiana, liberal y socialista "El mercado debe operar dentro de ciertos límites: la justicia social, la moral pública, la integridad espiritual de nuestra civilización, la supervivencia física de la especie humana. Marx pensaba, como todos en su época, que la naturaleza era una fuente de energía y que el hombre debería dominarla y explotarla. Ahora pensamos que la naturaleza es una fuente de vida que debemos respetar y venerar. Redescubrimos así ciertos elementos de nuestra herencia espiritual, tanto del cristianismo como del liberalismo y del socialismo" "५?

\subsection{Socialismo}

La reflexión sobre el socialismo que elabora Octavio Paz se decanta en una doble dirección: por un lado, su postura ante el socialismo como un ideal político que debe ser recuperado por su alcance ético; por otro, su postura ante el "socialismo autoritario", ante el cual el mexicano no oculta su actitud de rechazo frontal.

Sobre lo primero, Paz insiste en que el socialismo "es un ideal respetable. Y, en muchos aspectos, admirable. Debemos rescatar lo que tenga de rescatable. $Y$ tiene muchas cosas rescatables" ${ }^{\prime 4}$. Como luego veremos, $\mathrm{Paz}$ no se cansa de señalar los efectos perversos que trajo consigo el socialismo autoritario; sin embargo, no deja de llamar la atención acerca de lo valioso de las aspiraciones igualitarias que animaron a los mejores portavoces del movimiento socialista. "Ante las iniquidades del sistema capitalista — dice Paz - esos hombres se hicieron algunas preguntas. Esas preguntas siguen sin contestar" "9s. Una de las más importantes tiene que ver con la forma de resolver los graves problemas de injusticia y marginalidad propios del capitalismo. La tradición socialista, pese a

51. O. Paz, "La búsqueda del presente. (Conferencia Nobel. 1990)". En Fundación y" disidencia..., p. 40

52. O. Paz, "América en plural y en singular. (Entrevista con Sergio Maras)". En Ideas y costumbres..., p.149

53. Ibid., p. 150

54. Ibid., p. 156

55. O. Paz, "La otra voz". En La casa de la presencia..., p. 585 
los horrores históricos a los que dio lugar cuando se concretó, ha legado un ideal que puede ser explotado como principio corrector de los males generados por el capitalismo: la fraternidad, que debe convertirse en puente entre la libertad y la igualdad. "Sólo la fraternidad puede disipar la pesadilla circular del mercado"

Marx y el marxismo son un punto de referencia ineludible en esa recuperación de la tradición socialista. "Por una parte, esa fillosofía es parte de nosotros mismos y, en cierto modo, la llevamos en la sangre. Por la otra, renegar de su herencia moral sería renegar al mismo tiempo de la porción más lúcida y generosa del pensamiento moderno. Cierto, el marxismo es apenas un punto de vista - pero es nuestro punto de vista. Es irrenunciable porque no tenemos otro. Su posición es semejante a la de la geometría de Euclides: no rige en todos los espacios" ${ }^{\text {".7. }}$.

Recuperar la "herencia moral" del marxismo $-\mathrm{y}$, con ello, la herencia moral de la tradición socialista- exige articularlo con lo mejor de la tradición liberal; es de esa articulación de donde nacerá una filosofía política a la altura de los liempos. "El ideal de una sociedad justa es un legado muy valioso del socialismo. Debemos preservarlo. A su lado, la idea de dignidad de la persona humana, herencia del cristianismo. Por su parte, el liberalismo afirma que la democracia está lundada en la libertad y que la propiedad debe ser respetada porque es uno de los fundamentos de esa libertad. Sí, pero la propiedad no es ni puede ser el valor supremo. La riqueza debe estar sujeta al control de la sociedad como el poder público debe estar sujeto a la crítica de la sociedad"sx. Libertad y fraternidad, entonces, deben converger en los tiempos que corren. "El pensamiento de la era que comienza - si es que realmente comienza una era- tendrá que encontrar el punto de convergencia entre libertad y firaternidad. Debemos repensar nuestra tradición, renovarla y buscar la reconciliación de las grandes tradiciones política de la modernidad, el liberalismo y el socialismo. Me atrevo a decir, parafrascando a Ortega y Gasset, que este es "el tema de nuestro tiempo" ",").

Otras valoraciones muy distintas hace Paz del socialismo autoritario o, como él también lo llama, cl "socialismo irteal”. Más allá del juicio del mexicano acerca de las pretensiones cientílicas y práxicas del marxismo ${ }^{(1)}$, su postura ante las

56. Ibid.. p. 587

57. O. Paz. "Coniente alterna". En Ideas y costumbres II. Usos y simbolos. Obras compleras (X). México. FCE, 1996, pp. 625-626

58. O. Paz. "América en plural y en singular. (Entrevista con Sergio Maras)". En Idecas y (ostumbres..., p. 150)

59. O. Paz. "Ruptura y convergencia". En La casa de la presencia... p.p. 529-530

6(). "Sin revolución europea - dice Paz- el marxismo se derrumba. En efecto, el núcleo de la doctrina, su principio fundamental, consiste en ver en el proletariado a una clase universal revolucionaria destinada a cambiar la historia e inaugurar una nueva era. La evaporación clel agente histórico de la revolución mundial invalida al marxismo por partida cohle. como ciencia de la historia y como guía de la acción". O. Paz. "Itincrario". En Icleas y costumbres. I..., p. 34 
concreciones del proyecto socialista está marcada por una actitud abiertamente crítica. En este punto, la ex Unión Soviética le sirve de referencia histórica fundamental ${ }^{61}$. En su artículo "Los campos de concentración soviéticos" $(1951)^{62}$, Paz, a la luz de su reflexión sobre esa "aberración moral" que fueron los campos de trabajo forzado en la "patria de los trabajadores", esboza ideas que son claves para entender su visión del socialismo autoritario.

"El trabajo correctivo — dice- no es sólo expresión de la política del régimen; también lo es de su estructura social. Y, por lo tanto, de su naturaleza histórica: los condenados constituyen una de las bases de la pirámide burocrática. El problema de los campos soviéticos plantea el de la verdadera significación histórica del Estado ruso y de su incapacidad para resolver a favor de las clases productoras las contradicciones sociales del capitalismo"6?. Y más adelante: "la institución del 'trabajo correctivo sin privación de libertad' descubre nuevos matices jerárquicos en la sociedad soviética: en la base se encuentran los detenidos en los campos; en seguida, los condenados a los trabajos sin privación de libertad; después, los obreros y campesinos 'libres' (con las restricciones que todo el mundo conoce, privada la clase obrera de sus derechos más elementales de defensa: la libertad sindical y el derecho de huelga). Sobre esta masa viven los obreros especializados, los técnicos, las milicias. Arriba, la burocracia, la policía, la oficialidad y los generales, el partido, sus intelectuales y sus dignatarios. La URSS es una sociedad jerárquica. Lo cual no implica que sea inmóvil, aunque como todas las sociedades aristocráticas tienda a la petrificación"(14.

En otro texto, Paz remata así su visión de la sociedad soviética: "es una socieclad jerárquica con muy escasa movilidad, en la que las clases tienden a petrificarse en castas y dominada por una nueva categoría a un tiempo ideológica y militar: ideocracia y estratocracia, todo junto. Esta última descripción es particularmente justa: la Unión Soviética es una sociedad hecha a imagen y semejanril del Partido Comunista... el modelo dual del Partido Bolchevique ha sido la Iglesia y el ejército: sus miembros son clérigos y soldados; su ideal de comunidad, el convento y el cuartel. El cemento de la fusión entre el orden religioso y el orden militar es la ideología"(rs.

En esta caracterización del socialismo soviético, Paz hace notar su naturaleza jerárquica y petrilicada, al igual que su pobreza moral. Se trató de un sistema

61. Auncue también luvo como reterencia la expcriencia cubana, de la cual llegó a decir lo siguiente: "en Cuba ya está en marcha el latal proceso que convierte al partido revolucionario en una casta burocrática y al dirigente en césar". O. Paz. "Las conlesiones de Heberto Padilla”. En Ideas y costumbies I..... p. 172

62. En Idecas y costumbres 1..., p. 167-170

6.3. Ihicl.. p. 169

64. Ithid.

6.5. O. Paz. "El imperio totalitario". En Ideas y costumbres I.... pp. 31()-311 
fundado en la exclusión política y la explotación económica de aquellos a los que supuestamente iba a emancipar: los trabajadores.

A esos aspectos, el mexicano añade, como rasgo constitutivo del modelo, el terror como mecanismo de control social. "La noción bolchevique del poder político es inseparable de la noción de dictadura; esta última, a su vez, conduce al terror... En el marxismo había tendencias autoritarias que venían de Hegel. Pero Marx nunca habló de dictadura de un partido único, sino de algo muy distinto: dictadura temporal del proletariado en el periodo siguiente a la toma del poder. El leninismo introdujo un nuevo elemento: la noción de un partido revolucionario, vanguardia del proletariado, que asume en su nombre la dirección de la sociedad y de la historia... El sistema represivo soviético es una imagen invertida del sistema político creado por Lenin... La pirámide política que es la sociedad comunista se traduce en la pirámide invertida que es su sistema represivo"øn.

Un sistema represivo marcado por una profunda contradicción: se trató de una sociedad con una movilidad social casi nula, pero impulsada por una dinámica de continuas transformaciones tecnológicas y técnicas. "Por una parte, fosilización social y política; por la otra, continua renovación técnica e industrial. Esta contradicción, fuente de injusticia y desigualdad, provoca tensiones que el Estado sofoca con los métodos de todas las dictaduras: el reforzamiento del aparato represivo y una política de expansión exterior: Imperio y policía: estas dos palabras revelan que, a pesar de las diferencias considerables que las separan. hay una clara continuidad entre el Estado burocrático y el zarista" ${ }^{\text {"67. }}$.

El terror soviético tuvo un objetivo fundamental: el combate de las ansias de libertad que pudieran traducirse en una crítica del sistema. El sistema represivo soviético prestó especial atención al arte, especialmente a la literatura, pues desde muy temprano sus ideólogos cayeron en la cuenta de lo relevante que podía ser para sostener el proyecto bolchevique. El "realismo socialista" — "dogma burocrático-literario del estalinismo" "ix — se constituyó en la concreación de un arte en lunción de aquel proyecto. Pero pronto esos mismos ideólogos descubrieron que la creación artística podía salirse de los moldes burocráticos, para lo cual se diseñaron los mecanismos persecutorios que mantuvicran a raya a los posibles disidentes.

Las víctimas no tardaron en aparecer; una de las más signilicativas lue, en opinión clc Paz, Alexandr Solzhenitsyn, quien a raíz cle la publicación de su libro Archipiélago Gulag, terminó siendo expulsado - tras una sistemática campiña de difamación en su contra- de la ex Unión Soviética. No era para menos

66. O. Paz, "Polvos de aquellos lodos". En Ideas y costumbres I..., pp. 189-190

67. O. Paz, "El imperio totalitario". En Ideas y costumbres I.... p. 311

68. O. Paz, "Polvos de aquellos lodos". En Icleas y costumbres I..., p. 18.3 
el resquemor que habría de generar el libro de Solzhenitsyn en los círculos de poder soviéticos, toda vez que "Archipiélago Gulag no es únicamente una denuncia de los excesos del régimen estaliniano, por atroces que hayan sido, sino del sistema soviético mismo, tal como fue fundado por Lenin y los bolcheviques... no es un libro de filosofía política sino una obra de historia; más exactamente: es un restimonio --en el antiguo sentido de la palabra: los mártires son los testigosdel sistema represivo fundado en 1918 por los bolcheviques y que permanece intacto hasta nuestros días, aunque haya sido relativamente humanizado por Jruschov y hoy no ostente los rasgos monstruosos y grotescos del periodo estaliniano"ky.

Pese a lo anterior, el socialismo autoritario sedujo a incontables sectores sociales, tanto en Europa como en América Latina. Para Octavio Paz, a quienes más embrujó la "seducción totalitaria"70) fue a figuras del mundo intelectual -—el caso de Jean-Paul Sartre le merece a Paz una atención detenida ${ }^{71}$ - que no sólo callaron ante los crímenes más atroces del sistema represivo soviético — por ejemplo, los campos de trabajo forzado-, sino que se convirtieron en feroces detractores de quienes denunciaron las perversiones del sistema. Octavio Paz cita el siguiente texto de Sartre:

"Lals personas que en la URSS denuncian al sistema --dice el filósofo francés- son los intelectuales y no hay país, incluyendo los Estados Unidos, donde el intclectual se encuentre más desvinculado de las masas que en la URSS... Los obreros, en la medida en que ahora ganan más, no protestan, están satisfechos con el régimen, aprueban sus medidas; por ejemplo, la intervención soviética en Praga"'7?.

Y comenta Paz: "si la descripción que hace Sartre del estado de ánimo del proletariado ruso es exacta, es claro que la conversión del intelectual en obrero no sólo sería inútil, sino contraproducente. El intelectual-convertido-en-obrero sería la oveja negra de su clase de adopción como lo es ahora de su clase de origen. Es extraño que Sartre no se dé cuenta de que la situación rusa no es semejante a la de los países capitalistas... En la Unión Soviética los sindicatos todavía tienen que luchar por su independencia y todavía los obreros deben conquistar la libertad de asociación y de reunión. En Rusia la clase obrera está más explotada y oprimida que en los países capitalistas"7??

69. Ibicl., pp. 183-186

70. Esa "seducción" hizo que muchos intelectuales no quisieran ver los crímenes cometidos por el terror soviético. Esa ceguera fue calificada por Paz como "aberración intelectual" y "abyección". Cfr. "Intinerario"..., p. 34

71. Cfi. O. Paz, "Memento: Jean-Paul Sartre". En Excursiones/Incursiones. Dominio extranjero. Obras completas (II). México, FCE, 1994, pp. 392-402

72. J.P. Sartre, citado por Paz en "El parlón y la parleta". En Icleas y costumbres I..... pp. $176-177$

73. Ibicl., p. 177 
fundado en la exclusión política y la explotación económica de aquellos a los que supuestamente iba a emancipar: los trabajadores.

A esos aspectos, el mexicano añade, como rasgo constitutivo del modelo, el terror como mecanismo de control social. "La noción bolchevique del poder político es inseparable de la noción de dictadura; esta última, a su vez, conduce al terror... En el marxismo había tendencias autoritarias que venían de Hegel. Pero Marx nunca habló de dictadura de un partido único, sino de algo muy distinto: dictadura temporal del proletariado en el periodo siguiente a la toma del poder. El leninismo introdujo un nuevo elemento: la noción de un partido revolucionario, vanguardia del proletariado, que asume en su nombre la dirección de la sociedad y de la historia... El sistema represivo soviético es una imagen invertida del sistema político creado por Lenin... La pirámide política que es la sociedad comunista se traduce en la pirámide invertida que es su sistema represivo" "6t.

Un sistema represivo marcado por una profunda contradicción: se trató de una sociedad con una movilidad social casi nula, pero impulsada por una dinámica de continuas transformaciones tecnológicas y técnicas. "Por una parte, fosilización social y política; por la otra, continua renovación técnica e industrial. Esta contradicción, fuente de injusticia y desigualdad, provoca tensiones que el Estado sofoca con los métodos de todas las dictaduras: el reforzamiento del aparato represivo y una política de expansión exterior: Imperio y policía: estas dos palabras revelan que, a pesar de las diferencias considerables que las separan. hay una clara continuidad entre el Estado burocrático y el zarista" ${ }^{67}$.

El terror soviético tuvo un objetivo fundamental: el combate de las ansias de libertad que pudieran traducirse en una crítica del sistema. El sistema represivo soviético prestó especial atención al arte, especialmente a la literatura, pues desde muy temprano sus ideólogos cayeron en la cuenta de lo relevante que podía ser para sostener el proyecto bolchevique. El "realismo socialista" - "dogma burocrático-literario del estalinismo" "* — se constituyó en la concreación de un arte en lunción de aquel proyecto. Pero pronto esos mismos ideólogos descubrieron que la creación artística podía salirse de los moldes burocráticos, para lo cual se diseñaron los mecanismos persecutorios que mantuvieran a raya a los posibles disidentes.

Las víctimas no tardaron en aparecer; una de las más significativas fue, en opinión de Paz, Alexandr Solzhenitsyn, quien a raíz de la publicación de su libro Archipiélago Gulag, terminó siendo expulsado - tras una sistemática campaña de difamación en su contra- de la ex Unión Soviética. No era para menos

66. O. Paz. "Polvos de aquellos lodos". En Ideas y costumbres I.... pp. 189-190

67. O. Paz. "El imperio totalitario". En Ideas y costumbres 1 .... p. 311

68. O. Paz, "Polvos de aquellos lodos". En Ideas j' costumbres l..., p. 183 
el resquemor que habría de generar el libro de Solzhenitsyn en los círculos de poder soviéticos, toda vez que "Archipiélago Gulag no es únicamente una denuncia de los excesos del régimen estaliniano, por atroces que hayan sido, sino del sistema soviético mismo, tal como fue fundado por Lenin y los bolcheviques... no es un libro de filosofía política sino una obra de historia; más exactamente: es un restimonio —en el antiguo sentido de la palabra: los mártires son los testigosdel sistema represivo fundado en 1918 por los bolcheviques y que permanece intacto hasta nuestros días, aunque haya sido relativamente humanizado por Jruschov y hoy no ostente los rasgos monstruosos y grotescos del periodo estaliniano"ky.

Pese a lo anterior, el socialismo autoritario sedujo a incontables sectores sociales, tanto en Europa como en América Latina. Para Octavio Paz, a quienes más embrujó la "seducción totalitaria"70) fue a figuras del mundo intelectual ---el caso de Jean-Paul Sartre le merece a Paz una atención detenida ${ }^{71}$ - que no sólo callaron ante los crímenes más atroces del sistema represivo soviético — por ejemplo, los campos de trabajo forzado-, sino que se convirtieron en feroces detractores de quienes denunciaron las perversiones del sistema. Octavio Paz cita el siguiente texto de Sartre:

"Las personas que en la URSS denuncian al sistema —-dice el filósofo francés- son los intelectuales y no hay país, incluyendo los Estados Unidos, donde el intelectual se encuentre más desvinculado de las masas que en la URSS... Los obreros, en la medida en que ahora ganan más, no protestan, están satisfechos con el régimen, aprueban sus medidas; por ejemplo, la intervención soviética en Praga"??

Y comenta Paz: "si la descripción que hace Sartre del estado de ánimo del proletariado ruso es exacta, es claro que la conversión del intelectual en obrero no sólo sería inútil, sino contraproducente. El intelectual-convertido-en-obrero sería la oveja negra de su clase de adopción como lo es ahora de su clase de origen. Es extraño que Sartre no se dé cuenta de que la situación rusa no es semejante a la de los países capitalistas... En la Unión Soviética los sindicatos todavía tienen que luchar por su independencia y todavía los obreros deben conquistar la libertad cle asociación y de reunión. En Rusia la clase obrera está más explotada y oprimida que en los países capitalistas"7?.

69. Ibid., pp. 183-186

7). Esa "seducción" hizo que muchos intelectuales no quisieran ver los crímenes cometidos por el terror soviético. Esa ceguera fue calificada por Paz como "aberración intelectual" y "abyección". Cfr. "Intinerario"..., p. 34

71. Cli. O. Paz, "Memento: Jean-Paul Sartre". En Excursiones/Incur-siones. Dominio extranjero. Obras completas (II). México, FCE, 1994, pp. 392-402

72. J.P. Sartre, citado por Paz en "El parlón y la parleta". En Ideas y costumbres l.... pp. 176-177

7.3. Ibicl., p. 177 
En resumen, la actitud de Paz hacia el "socialismo irreal" fue de rechazo crítico. De este rechazo, el mexicano derivó la gran tarea política del hombre contemporáneo: el rechazo del autoritarismo en todas sus manifestaciones. "Nuestro tiempo - escribió- es el de la peste autoritaria: si Marx hizo la crítica del capitalismo, a nosotros nos falta hacer la del Estado y las grandes burocracias contemporáneas, lo mismo las del Este que las del Oeste. Una crítica que los latinoamericanos deberíamos completar con otra de orden histórico y político: la crítica del gobierno de excepción por el hombre de excepción, es decir, la crítica del caudiIlo, esa herencia hispanoárabe"74. O, en otras palabras, la situación actual plantea una doble exigencia moral y política: "la primera es romper con el mito de una URSS socialista; la segunda, establecer la democracia interna en los partidos comunistas. Esto último significa revisar la tradición leninista en su raíz misma. Si los partidos comunistas quieren dejar de ser órdenes religiosas y militares para convertirse en auténticos partidos políticos, deben comenzar por practicar la democracia en casa y denunciar a los tiranos ahí donde los haya, sea en Chile o en Vieınam, en Cuba o en Irán"7s.

\subsection{Nacionalismo}

El examen que hace Octavio Paz del nacionalismo arranca de una constatación: su resurgimiento tras el colapso del bloque socialista. "En 1991 se desintegró una construcción política comenzada cinco siglos antes. ¿Definitivamente? Nadie lo sabe: la historia es una caja de sorpresas. En todo caso: aparte de ser hipotética, la reconstitución del Imperio ruso no es tarea para mañana. Es claro que, en cambio, que la desintegración ha fortalecido a los nacionalismos. La única ideología sobreviviente de las crisis, guerras y revoluciones de los siglos XIX y XX ha sido el nacionalismo" "7n. Al derrumbe del bloque soviético siguió cl rebrote nacionalista debido a una razón fundamental: "las viejas nacionalidades sometidas por el zarismo y el comunismo nunca perdieron sus características propias y sus tradiciones culturales, lingüísticas y religiosas... De ahí que la quiebra del Estado creado por Lenin y sus compañeros en 1917 haya producido una inmediata rebelión de las naciones sometidas" 77 . En otro texto remata esta idea: "asistimos — dice- al renacimiento de ideas, creencias y costumbres humilladas durante más de medio siglo. Es una verdadera resurrección de las culluras tradicionales" $7 x$.

74. O. Paz, "Las confesiones de Heberto Padilla". En Icleas y' costumbres I..., p. 172

75. O. Paz. Vistazo al Viejo Mundo". En Ideas y' costumbres I...,. p. 279

76. O. Paz, "Itinerario". En Icleas y, costumbres I..., p. 52

77. O. Paz, "Un escritor mexicano ante la Unión Soviética". En Ideas y costumbres I..., p. 241

78. O. Paz, "Fin de un sistema", En Ideas y costumbres I..., p. 382 
Paz ve en la "resurrección del nacionalismo" un fenómeno explosivo que, como la "partícula de indeterminación en física..., hace vacilar todos los cálculos políticos. Está en todas partes, dinamita todos los edificios y exacerba todas las voluntades" $"$. . Esta fuerza del nacionalismo estriba en su dimensión pasional, la cual desborda a la lógica política y a la comprensión racional. "El nacionalismo introduce un elemento pasional, irreductible a la razón, intolerante y hostil al punto de vista ajeno. Lo más grave: es una pasión contagiosa. Fundado en lo particular y en la dilerencia, se asocia con todo lo que separa a una comunidad de otra: la raza, la lengua, la religión. Su alianza es frecuente y letal por dos razones. La primera porque los lazos religiosos son más fuertes; la segunda, porque la religión es por naturaleza, como el nacionalismo, reacia a la mera razón"ki).

Esa reivindicación nacionalista de lo particular y lo diferente es una reivindicación apasionada y sangrienta que exige matar al enemigo o el suicidio ${ }^{\mathrm{k}}$. Unida a la pasión religiosa, se transforma en un peligroso "nacionalismo lundamentalista", cuya "violencia puede desbordarse y... ahogar a los movimientos democráticos en un mar de agitaciones y, quizás, de sangre" "\$2, tal como lo ponen de maniliesto el islamismo en una de sus versiones más violentas: el chí́smo. Sus seguidores, "fieles a la tradición del Islam —religión de combatientes - desde el principio se organizaron militarmente. Así, las bandas chiílas que siguen a Jomeini y sus ayatolas figuran los mismos elementos básicos que definen a los partidos comunistas: la fusión entre lo militar y lo ideológico"k?.

No obstante, los peligros de los desbordes nacionalistas no impiden a Paz reconocer la legitimidad que puedan tener como reivindicación de lo particular de las culturas y las tradiciones de cada pueblo. "No propongo una extirpación de los nacionalismos. Sería imposible y, además, funesto: sin ellos los pueblos y las culturas perderían individualidad, carácter. Son el elemento vivaz de la historia, la sal que da variedad a cada comunidad. He sido y soy partidario de la diversidad. Creo en el genio particular de cada pueblo; creo también que las grandes creaciones, sean colectivas o individuales, son el resultado de la fusión de elementos distintos e incluso contrarios. La cultura es hibridación" ${ }^{\text {" }}$.

¿Cuál es el "remedio" contra el nacionalismo en lo que tiene de perverso? "El remedio contra el nacionalismo no es el imperio sino la confederación de naciones" "ks. Se trata de rescatar lo que en el nacionalismo hay de creativo, es decir, de reconocimiento de lo diverso, pero sin asumir sus aspectos disolventes.

79. O. Paz, "Itinerario". En Ideas y costumbres I..., pp. 52-53

80. Ibid. p. 53

81. O. Paz, Un escritor mexicano...". p. 241

82. O. Paz, "Fin de un sistema"... En Ideas y costumbres I..., p. 382

83. O. Paz. "Revuelta y resurrección". En ldeas y costumbres l.... p. 337

84. O. Paz, "Itinerario". En Ideas y" costumbres $I$..., p. 53

85. Ibid. 
Ante éstos, nada mejor que una solución comunitaria ${ }^{\text {xt }}$ que tenga como eje articulador el diálogo permanente entre las distintas culturas y civilizaciones, lo cual puede ser posibilitado en un marco democrático. "Las grandes civilizaciones han sido hechas a través de diálogos entre distintas culturas. Soy partidario del diálogo porque soy partidario de la diversidad. Cuando la unidad se transtorma en uniformidad, la sociedad se petrifica. Esto fue lo que les pasó a los comunistas. Para vivir, la democracia tiene que albergar elementos contradictorios que la hagan permanentemente crítica. El diálogo, la crítica, el intercambio de opiniones: eso es la vida política y eso es la cultura"k7.

En este diálogo de culturas y civilizaciones, Occidente debe visitar Oriente, abrevar de sus tradiciones religiosas y filosóficas, al igual que debe hacer el Oriente en su relación con las tradiciones occidentales. "Creo que en el Occidente apenas estamos descubriendo lo que el Oriente descubrió hace milenios. Pero ellos también están descubriendo cosas que el Occidente descubrió primero: la democracia, por ejemplo, y la ciencia... Senderos plurales, no un solo Camino. En la imaginación religiosa, politeísmo, no monoteísmo. La convergencia de tiempos, no la casualidad lineal. Sincronía. Ausencia de utopías. La estética del momento. Estas son las nuevas condiciones del Occidente que hemos estado analizando. Parece ser que, al 'Final de la historia', el Oriente se encuentra con el Occidente"xx.

\subsection{Revolución-revuelta ${ }^{89}$}

La reflexión de Octavio Paz sobre el tema de la "revolución" se relaciona directamente con otro tema que llamó su atención: la "revuelta". Revolución y revuelta, apuntan, cada una según su especificidad, a cambios socio-políticos y culturales de gran envergadura. La primera hace referencia a "movimientos sociales que proponen un programa universal de cambios. La universalidad revolucionaria no depende de una revelación sobrenatural sino de la razón" ". La segunda hace referencia al caos y al desorden. "En revolución las ideas de regreso y movimiento se funden en la de orden; en revuelta esas mismas ideas denotan

86. O. Paz, "Respuestas nuevas a preguntas viejas (Entrevista con Juan Cruz)". En Ideas y costumbres I..., pp. 486-487

87. O. Paz, "América en plural y singular". En Ideas y costumbres $I$..., p. 153

88. O. Paz, "El Occidente se vuelve hacia el Oriente al final de la historia". En VVAA, Fin de siglo. Grandes pensadores hacen reflexiones sobre nuestro tiempo. México, McGraw Hill, 1996, p. 179

89. Hay un tercer término asociado a estos dos, que ocupa la atención de Paz: "rebelión". "La relación es jerárquica: revuelta vive en el subsuelo del idioma; rebelión es individualista; revolución es palabra intelectual y alude, más que las gestas de un héroe rebelde, a los sacudimientos de los pueblos y a las leyes de la historia. Rebelión es voz militar; viene de bellum y evoca la imagen de la guerra civil". O. Paz, Revuelta, revolución, rebelión". En Icleas y costumbres II..., p. 589

90. O. Paz, "Itinerario". En Ideas y costumbres I..., p. 47 
desorden. Así, revuelta no implica ninguna visión cosmogónica o histórica: es el presentc caótico o tumultuoso"'”!

El paradigma de una revolución moderna lo constituye la revolución francesa. El gran intérprete de los procesos revolucionarios europeos: Karl Marx, para quien la contradicción histórica entre el proletariado y la burguesía se convertía en cl supuesto fundamental de los cambios revolucionarios. Esa contradicción -exaccrbada por el desarrollo de unas fiserzas productivas en expansión crecientehacía prever que en los países capitalistas más avanzados estallaría la revolución. "Para los clásicos del pensamiento revolucionario del siglo XIX, la Revolución sería la consecuencia del desarrollo: el proletariado urbano pondría fin al desequilibrio entre el progreso técnico y económico (el modo de producción indusIrial) y el nulo o escaso progreso social (el modo de propiedad capitalista)"',?

Ahora bien. la revolución proletaria no sólo tendría como base el desequilibrio aludido. sino que estaría inspirada en un programa de emancipación universal. cuya seguridad de éxito provendría de la racionalidad de sus conductores. Así, los revolucionarios modernos — los comunistas-vendrían a ser los mejores exponentes de la idea de revolución: "revolución es la idea encarnada en un grupo y convertida en un arma de combate como en instrumento para edificar una nucva sociedad. Revolución: teoría del cambio. acto que lo realiza y construcción (lc la casa del futuro. El revolucionario es el tipo cle hombre que reúne los atributos del lïlósofo, del estratega y del arquitecto social"'??

El hombre revolucionario es un hijo de la modernidad, puesto que la misma idca de revolución es la expresión extrema de dinámica de cambio que recorre a la época moderna. "El concepto de revolución, en el triple sentido que acabo de mencionar, fue totalmente desconocido por las sociedades del pasado, lo mismo en Occidente que en Oriente. Aquellas sociedades, sin excluir a las primitivas, vieron siempre con desconfianza y aun con horror el cambio; todas ellas veneraron a un principio invariable, fuese un pasado arquetípico, una divinidad o cualquier otro concepto que significase la superioridad del ser sobre el devenir. La modernidad ha sido única en la sobrevaloración del cambio. Esta sobrevaloración explica, además, la emergencia de la idea de revolución"'.4. Defender la idea revolucionaria ha sido delender - luchar por - la abolición del presente y la fundación de una nueva rcalidad. La revolución es una "ruptura" y un "comienzo". Es, asimismo, "una pasión generosa y un fanatismo criminal, una iluminación y una obscuridad".s.

91. O. Paz, Revuelta, revolución, rebelión". En Ideas y costumbres II..., p. 589

92. O. Paz, "Postdata". El laberinto de la soledad. México, FCE, 1999, p. 237

93. O. Paz, "Itinerario". En Ideas y costumbres I..., p. 16

94. Ibicl.

95. Ibicl., p. 17 
Distinto ha sido el carácter de las revueltas que se han sucedido en el siglo $\mathrm{XX}$ en América Latina, Asia y África, las cuales "carecían de esa característica (lual: ser un programa universal lundado en la universalidad de la razón. Pensé que a csos movimientos les convenía más la noción cle revuelra que de revolucirin. Revuelta no en el sentido que había dado Camus a la palabra: reacción inclividual, respuesta del esclavo y el sometido, sino en el sentido tradicional y de uso común, referido siempre a la colectividad. Los protagonistas de esas revueltas no cran ni los individuos ni las clases sociales sino las naciones" ${ }^{\prime \prime}$. Esas naciones qucrían liberarse del tutelaje de Occidente - la mejor expresión de ello lueron los movimientos de liberación nacional-, pero "se apropiaban de sus conceptos políticos: nación. democracia, socialismo. Esta contradicción era más ostensible si sc reparaba en otra circunstancia: las élites que encabezaban todas esas revueltas habían sido educadas con métodos europeos y, con frecuencia, en las universidades (le Europa. La contradicción, por lo demás, no sólo era (y es) política, sino histórica y cultural: esos movimientos exaltaban sus culturas tradicionales y, simultáneamente, buscaban a toda costa la modernización de sus países"')7.

La revuelta, pues, lue un movimiento que, a diferencia de la revolución, no estuvo orientado por un proyecto fundado en la razón. La revuelta tampoco apuntó. como la revolución, a la lundación de algo nuevo, sino a la recuperación clel pasado y, al mismo liempo, a su modernización: "la revuelta significaba, contradictoriamente, la resurrección de viejas culturas y su occidentalización")x. Por último. la revuelta no tuvo como protagonista a un grupo social particular - una clasc. por ejemplo-, sino que es llevada adelante por unas élites que creen encarnar los intereses del conjunto de la nación. Todos estos aspectos hicieron de las revueltas en el Tercer Mundo algo explosivo y peligroso.

Uno de los rasgos más llamativos de la revuelta es la carencia de un programa de acción. "Heterogeneidad y contradicción definieron desde el principio a los movimientos del Tercer Mundo. Lo primero les impidió unirse y presentar un programa común. La carencia de programa precipitó la segmentación y ésta la caída en estrechas pasiones tribales y en 'fundamentalismos religiosos" ${ }^{\text {" } / 1 \text {. }}$.

En segundo lugar, la revuelta, por la recuperación del pasado que la anima, tiene una dimensión de arcaísmo — de regreso al pasado - que puede convertirse en una verdadera obsesión para quienes dirigen el movimiento. "Un ejemplo entre muchos: la caída del Sha, un déspota modernizador, no llevó a Irán a la democracia sino a un régimen teocrático. La revuelta de Irán, saludada con entusiasmo por muchos intelectuales europeos y norteamericanos, fue un paso hacia atrás"|(k).

96. Ibid.. p. 47

97. Ibid.

98. Ibicl., p. 48

9). Ibicl.

100. Ibid. 
En tercer lugar, la revuelta puede convertirse en el terreno propicio para el cultivo de las violencias más atroces y de las pasiones más bajas. "La revuelta, como su nombre lo indica, lleva en el vientre pasiones y tendencia opuestas. En su forma más extrema, esas contradicciones se resuelven en estallidos; en sus lormas moderadas, en compromisos hipócritas que ponen en entredicho la coherencia del movimiento $y$, a veces, su legitimidad. El nacionalismo indio es un ejemplo... el nacionalismo indio cambió de signo: no defendió al pueblo de la dominación extranjera sino que impuso sobre los otros pueblos su autoridad"|01.

En definitiva, los resultados de las revueltas han sido, por lo general, desastrosos. "La heterogeneidad y la contradicción se resolvieron con frecuencia en la aparición de regímenes políticos híbridos, a veces monstruosos y otras grotescos. Bizarras invenciones de la patología histórica, como la democracia dirigida de Indonesia y los variados socialismos que florecieron en algunos países asiáticos y africanos... Tiranías disfrazadas de socialismo, satrapías con nombre de república"|(1). Allí donde el ideal abanderado fue el socialismo, las perversiones no fueron desastrosas. "Para Marx y Engels, el socialismo sería la consecuencia del desarrollo industrial; fue escandaloso que muchos marxistas aprobasen, sin pestañear, la farsa de varios gobiernos de Asia y África, empeñados en convertir el socialismo en un método de desarrollo industrial y económico. Los socialismos de los países subdesarrollados fueron, desde el punto de vista de la teoría, un contrasentido y, desde el de la política y la economía, un desastre colosal. No dejaron sino ruinas" 103 . En América Latina, dejaron el régimen de Fidel Castro, mismo que se inició a partir de un levantamiento contra una dictadura, pero que ahora niega al pueblo cubano el derecho a su autodeterminación ${ }^{1(24}$.

\section{Idea de hombre}

La obra de Octavio Paz es abundante en profundas reflexiones de carácter lïlosófico sobre el hombre, no dichas incidentalmente, sino expresamente meditadas y formuladas con hondura metafísica. Es cierto, Paz no es - ni él pretendió serlo- un filósofo latinoamericano; sin embargo, en sus elaboraciones conceptuales no dejó de lado los aportes que la indagación filosófica propiamente dicha podía ofrecerle. Conoció a los clásicos de la filosofía griega - Heráclito, Platón, Aristóteles-, la filosofía política moderna - Montesquieu, Montaigne, Locke, Hobbes, Rousseau, Marx - el pensamiento filosófico español -Ortega, Zubiri-, y el pensamiento fillosófico contemporáneo —Lévi-Strauss ${ }^{1114}$, Sartre,

1()1. Ibicl.

1()2. Ibicl.. p. 49

103. Ibicl.

1(1)4. Ibicl.

105. Para O. Paz, los escritos de Lévi Strauss revisten una importancia antropológica, lil osófica y estética. "Lévi-Strauss - escribe- desconfía de la filosofía pero sus libros son un diálogo permanente. casi siempre crítico, con el pensamiento filosófico 
Merleau-Ponty, Santayana-, sólo para mencionar algunos de las fuentes y nombres que aparecen frecuentemente en sus escritos.

Paz frecuentó a esos autores y sus ideas —al igual que frecuentó las tradiciones de pensamiento oriental ${ }^{116}$ - acuciado por un interés: comprender al hombre y sus misterios. En una de las formulaciones más cabales de lo que es hombre, Paz lo caracteriza (¿define?) así: "el hombre, el inventor de ideas y de artefactos, el creador de poemas y de leyes, es una criatura trágica e irrisoria: es un incesante creador de ruinas"1(17.

Ese creador de ruinas no está solo: está con otros; con esos otros -que somos todos, dice Paz - hace la historia, en cuya constitución misma aparece — por ser obra humana - el mal como algo ineludible. "La historia es lo que nosotros hacemos. Nosotros: los vivos y los muertos. Pero, ¿somos acaso responsables de lo que hicieron los muertos? En cierta medida, sí lo somos: ellos nos hicieron y nosotros continuamos sus obras, las buenas y las malas. Todos somos hijos de Adán y Eva, la especie humana tiene los mismos genes desde que apareció en la tierra. La historia chorrea sangre desde Caín... Ni las estrellas ni los átomos, ni las plantas ni los animales, conocen el mal. El universo es inocentc, incluso cuando sepulta el continente o incendia una galaxia. El mal es humano, exclusivamente humano. Pero no todo es maldad en el hombre. El nido clel mal está en su conciencia, en su libertad. En ella está también el remedio, la respuesta contra el mal... luchar contra el mal es luchar contra nosotros mis$\operatorname{mos} " 10 x$.

El hombre, pues, en un ser contradictorio, difícil de encasillar de un modo definitivo como totalmente bueno o absolutamente malo: el gozne entre la maldad y la bondad, entre la cobardía y la valentía, lo constituye la libertad. Asimismo, el hombre, como individuo, está abierto a los otros, con quienes dialoga, para reconocerse, encontrarse $y$, también, perderse. El pucnte entre los hombres cs cl lenguaje ${ }^{(t)}$; y ello por una razón esencial: "el hombre es inseparable de las

y especialmente con la fenomenología... su tema central es el lugar del hombie en el sistema de la naturaleza". O. Paz, "Claude Lévi-Strauss o el nuevo festín de Esopo". En Ideas y costumbres II. Usos y simbolos. Obras completas (X). México, FCE. 1996, p. 491

1()6. C.ir.. O. Paz. "Vislumbres de la India". En Icleas y costumbres II... pp. 357-490

107. O. Paz. "Itinerario". En Icleas y costumbres I..., p. 66

l()8. Ibicl.

1() (). Con hondura filosólica, Paz se hace la siguiente pregunta: “„es posible una filosofía sin lenguaje?". Al respecto. dice lo siguiente: "el equívoco de toda filosolía depende de su fatal sujeción a las palabras. Casi todos los fílósofos afirman que los vocablos son instrumentos groseros. incapaces de asir la realidad... Los símbolos son también lenguaje. aun los más abstractos y puros. como los de la lógica y la matemática... imaginemos lo imposible: una filosofía dueña de un lenguaje simbólico o matemático sin referencia a las palabras. El hombre y sus problemas - tema esencial de toda 
palabras. Sin ellas es inasible. El hombre es un ser palabras... La palabra es el hombre mismo. Estamos hechos de palabras. Ellas son nuestra única realidad o, al menos, el único testimonio de nuestra realidad. No hay pensamiento sin lenguaje, ni tampoco objeto de conocimiento: lo primero que hace el hombre frente a una realidad desconocida es nombrarla, bautizarla"|10. Dicho de otro modo: "los hombres hablamos palabras que designan esto o aquello; no decimos cosas, sino nombres de cosas. Por esto las palabras tienen sentido, dirección: son puentes entre nosotros y las cosas y seres del mundo"'II.

Entonces, sin lenguaje no hay ser humano, no hay hombre; es algo "indivisible e inseparable del hombre. El lenguaje es una condición de la existencia del hombre y no un objeto o un sistema de signos que podemos aceptar o desechar" "I?. Así pues. "el hombre es hombre gracias al lenguaje, gracias a la metálora original que lo hizo ser otro y lo separó del mundo natural. El hombre es un ser que se ha creado a sí mismo al crear un lenguaje. Por la palabra, el hombre cs una metálora de sí mismo" "1?.

Por la palabra, el hombre se separa de la naturaleza, se humaniza en relación con sus congéneres, con quienes se comunica a través de ella. Por la palabra — por el "pacto verbal" - es que se hace posible la sociedad: "el fundamento de la sociedad no es el pacto social sino... el pacto verbal. La sociedad humana comienza cuando los hombres empiezan a hablar entre ellos, cualquiera que haya sido la índole y la complejidad de esa conversación: gestos y exclamaciones o, según hipótesis más verosímiles, lenguajes que no difieren de los nuestros. Nuestras instituciones políticas y religiosas tanto como nuestras ciudades de piedra y de hierro rcposan sobre lo más frágil y evanescente: sonidos que son sentido. Una metálora: el pacto verbal. es el fundamento de nuestras sociedades"1/4.

De este modo, la palabra nos abre a la experiencia y a la comunicación con los demás. Pero es también vínculo con la realidad exterior, con las cosas: "la distancia entre la palabra y el objeto... es consecuencia de otra: apenas el hombre adquirió conciencia de sí, se separó del mundo natural y se hizo otro en el seno de sí mismo. La palabra no es idéntica a la realidad que nombra porque

lilosofía- no tendrían cabida en ella... toda lilosolía que se sirve de palabras está condenada a la servidumbre cle la historia, porque las palabras nacen y mueren. como los hombres. Así. en un extremo, la realidad que las palabras no pueden expresar: en el otro, la realidad del hombre que sólo puede expresarse con palabras". O. Paz. "El lenguaje". En La casa de la presencia. Poesía e historia. Obras compleIas (l). México. FCE. 1995. p. 58

II (). Ihid.

111. O.Paz. "Decir sin decir: Vicente Huidobro". En Fundación y' disidencia.... p. 182

1 12. O. Paz. "El lengua je". En La casa de la presencia... pp. 58-59

113. Ibicl. . pp. 6I-62

I 14. O. Paz. "El pacto verbal". En Ideas y' costumbres II.... p 6.58. 
entre el hombre y las cosas - y más hondamente, entre el hombre y su ser- se interpone la conciencia de sí. La palabra es un puente mediante el cual el hombre trata de salvar la distancia que lo separa de la realidad exterior. Mas esa distancia forrna parte de la naturaleza humana. Para disolverla, el hombre debe renunciar a su humanidad, ya sea regresando al mundo natural, ya trascendiendo las limitaciones que su condición le impone"115.

Palabra: puente entre los hombres; puente entre el hombre y las cosas; puente entre los hombres y la "otra orilla", donde se encuentra el misterio de la realidad, lo "sagrado" de ella. "Lo Otro nos repele: abismo, serpiente, delicia, monstruo bello y atroz... Ese Otro es también yo. La fascinación sería inexplicable si el horror ante la 'otredad' no estuviese, desde su raíz, teñido por la sospecha de nuestra final identidad con aquello que de tal manera nos parece extraño y ajeno... El precipitarse en el Otro se presenta como un regreso a algo que fuimos. Cesa la dualidad, estamos en la otra orilla. Hemos dado el salto mortal. Nos hemos reconciliado con nosotros mismos" $" 16$.

Cuando eso sucede, al hombre se le abren tres posibilidades: la religión, el silencio o la palabra poética, inseparables la una de la otra, porque "lo sagrado es el sentimiento original, del que se desprenden lo sublime y lo poético"117. Y todo ello está inscrito en la naturaleza humana, porque el hombre "es un ser que se asombra; al asombrarse, poetiza, ama, diviniza. En el amor hay asombro, poetización, divinización y fetichismo. El poetizar brota también del asombro y el poeta diviniza como el místico y ama como el enamorado. Ninguna de estas experiencias es pura; en todas ellas aparecen los mismos elementos, sin que puede decirse que uno es anterior a los otros" "11x.

Si la experiencia de lo sagrado es "una revelación de nuestra condición original... es una respuesta a esa condena a vivir en mortalidad que es todo hombre"|'", la palabra poética - la palabra que inventa el poeta- permite "hacerle frente al silencio o al caos ruidoso y ensordecedor": "la palabra poética es revelación de nuestra condición original porque por ella el hombre efectivamente se nombra otro, y así él es, al mismo tiempo, éste y aquél, él mismo y el otro"|?".

En lin, el hombre es un ser de palabras que tiene la posibilidad, a partir de cllas, cle ser 'otro'. La palabra poética — la "voz poética"- es la que permite dar ese "salto mortal" en que consiste "salir de nosotros mismos", "entregarnos"

1 1.5. Ibid., pp. 62-63

I I G. Ibicl., p. 144

117. O. Paz. "La revelación poética". En La casa de la presencia. Poesia e historia..., p. I5I

I 18. Ibicl. p. 1.52

I 19. Ibid., p. 154

120. Ibicl., pp. 182-183 
y “perdernos en el 'otro"'/21. La poesía es, en este sentido, esencialmente erótica, puesto que el ser mismo del hombre es erotismo. La inspiración —esa fuerza interior que sostiene el acto de escribir poemas- es "esa voz extraña que saca al hombre de sí mismo para ser todo lo que es, todo lo que desea: otro cuerpo, otro ser. La voz del deseo es la voz misma del ser, porque el ser no es sino deseo de ser"122. El cuerpo ajeno es lo otro que se desea: es un obstáculo o un puente que tiene que ser traspasado. "El deseo, la imaginación erótica, la videncia erótica, atraviesa los cuerpos, los vuelve transparentes. O los aniquila. Más allá de ti, más allá de mí, por el cuerpo, en el cuerpo, más allá del cuerpo, queremos ver algo. Ese algo es la fascinación erótica, lo que me saca de mí y me lleva a ti: lo que me hace ir más allá de ti. No sabemos a ciencia cierta lo que es, excepto que es algo más. Más que la historia, más que el sexo, más que la vida, más que la muerte".

\section{América Latina}

Este último apartado tiene como propósito exponer las ideas que sobre América Latina elaboró Octavio Paz a lo largo de su trayectoria intelectual. No se trata, conviene decirlo, de un apartado adicional a sus reflexiones críticas sobre la literatura o la política, sino de una preocupación que recorre permanentemente las páginas de la obra del mexicano, siempre atento a iluminar la especificidad de América Latina ${ }^{123}$ —en lo económico, lo político o lo cultural- desde lo que otras experiencias históricas pudieran aportar para ello. Al leer los escritos de Paz, una conclusión se impone: la comprensión de América Latina —de su historia, sus problemas y su destino- siempre estuvo en el centro de sus preocupaciones intelectuales, incluso cuando sus reflexiones se centraron en temas tan especializados, como las religiones orientales o los mecanismos de la creación poética.

La rcllexión de Paz sobre América Latina se decanta en básicamente tres direcciones: independencia, modernidad y "excentricidad" latinoamericana. En lo quc sigue, haremos una aproximación somera a esos temas.

a) Independencia. La indagación que Paz hace sobre la independencia tiene como punto de partida su análisis cle la socicdad colonial. Tanto en el libro El laberinto de la soledad como en el libro Sor Juana Inés de la Cruz o las rrampas de la fe, cl mexicano de jó plasmadas unas ideas densas sobre el carácter del orden colonial: se trató de un orden — nos dice en el primero de los escritos aludidos- "hecho para durar. Quiero decir, una sociedad regida conforme a

121. Ibid.. p. 184

122. Ilicl.

123. Y. por supuesto, de México. país al cual dedicó sendos cstudios: El laberinto de la soleclad (ya citado) y Sor. Juana Inés de la Cruz o las trampas de la fe. México. FCE. 1996 . 
principios jurídicos, económıcos y religiosos plenamente coherentes entre sí y que cstablecían una relación viva y armónica entre las partes y el todo. Un mundo suliciente, cerrado al exterior, pero abierto a lo ultra terreno"124. Fue una sociedad penetrada en todos sus poros por el catolicismo: "el catolicismo es el centro de la sociedad colonial porque de verdad es la luente de vida que nutre las actividades. las pasiones, las virtudes y hasta los pecados de los siervos y señores, de luncionarios y sacerdotes, de comerciantes y militares. Gracias a la religión el orden colonial no es una mera superposición de nuevas formas históricas, sino un organismo viviente"124.

Un catolicismo ortodoxo -imbuido de la contrarreforma, el espíritu de crurada y el neotomismo ${ }^{126}$ - preservó a la sociedad colonial de la amenaza del cambio cconómico, social, político y cultural. Ese catolicismo orientó el quehacer tanto cle artistas como de universitarios; de los cortesanos, los sacerdotes y los luncionarios. "Si la arquitectura es el arte que mejor manifiesta el carácter y lass tendencias de una sociedad, Nueva España fue una vasta plaza en la que se entrentaban y conlirontaban el palacio, el ayuntamiento y la catedral: el príncipe y su cortc, el pueblo en su pluralidad de jerarquías y jurisdicciones; la ortodoxia religiosa. Fuera de la plaza, otras tres construcciones: el convento, la universidad y la lortaleza. El convento y la universidad eran los centros del saber; la fortaleza delicndía a.la nación del exterior. Pero el convento y la universidad también eran lortalczas: no delendían a la Nueva España de los piratas y de los nómadas sino (lel tiempo... El cnemigo era la historia, esto es, la forma que asumió el tiempo histórico en la Edad Moderna: la crítica. Nueva España no estaba hecha para cambiar sino para durar... Su ideal era la estabilidad y la permanencia; su visión de la perlección era imitar, en la tierra, el orden elerno"|27.

Los movimientos independentistas no logran romper con el legado colonial, sobre todo con cl legado de sus instituciones económicas. En opinión de Paz, la matriz misma de los movimientos independentistas debe ubicarse más en "la tradición de las luchas de Cataluña y Portugal contra la hegemonía de Castilla (jue en la historia de las revoluciones modernas"'2k. En virtud de ello, la independencia no buscó tanto la fundación de un nuevo orden social y económico —algo propio de las revoluciones modernas - como la negación de España. Es cierto, el propósito era reemplazar "el régimen monárquico español, absolutista y católico, por uno republicano, democrático y liberal"|2". Los ideales que inspiraron ese

124. O. Paz. El laberinto.... pp. |1()-1।1

125. Ihid.. p. 111

126. "El neolomismo - dice Paz- considera a la sociedad como un sistema jerárquico en el cual cada persona y cada grupo sirven un propósito de orden general y universal que los trasciende". O. Paz. Sor Juana Inés... p. 49

127. Ibicl.. p. 66

128. Ibicl., p. 29

129. O. Paz, "Literatura y crítica”. En Fundación y disidencia. Dominio hispánico..., p. 63 
propósito lueron los ideales de democrático-liberales, tomados de la Revolución cle Independencia de los Estados Unidos y de la Revolución firancesa. En el primer caso, "la Revolución cle Independencia separó a los Estados Unidos de Inglaterra pero no cambió ni se propuso cambiar su religión, su cultura y los principios que habían fundado a la nación"1 z". En el segundo caso, "en Francia había una relación orgánica entre las ideas revolucionarias y los hombres y las clases que las encarnaban y trataban de realizarlas... Por más abstractas y aun utópicals que pareciesen, correspondían de alguna manera a los hombres que las habían pensado y a los intereses cle las clases que las habían hecho suyas" "1".

Por ambos lados, la situación latinoamericana fue distinta. Ante todo, "la Independencia hispanoamericana fue un movimiento no sólo de separación sino de negación de España"' ‘2. A su vez, los ideales liberales y democráticos, abanderados por los caudillos hispanoamericanos, "eran máscaras; los hombres y las clases que gesticulaban detrás de ellas eran herederos directos de la sociedad jerárquica española: hacendados, comerciantes, militares, clérigos, funcionarios. La oligarquía latifundista y mercantil unida a las tres burocracias tradicionales: la del Estado, la del Ejército - y la de la Iglesia. Nuestra Revolución de Independencia no lue sólo una autonegación sino un autoengaño. El verdadero nombre de nuestra democracia es caudillismo y el de nuestro liberalismo es autoritarismo" $"$ "1?.

En suma, los procesos indepedentistas hispanoamcricanos estuvieron atravesados por una contradicción, origen de taras como la mentira política, el fraude y la manipulación ciudadana: el divorcio entre los ideales y la realidad. "Las ideas republicanas y democráticas de los grupos que dirigieron la lucha por la independencia no correspondían a la realidad histórica, a la realidad real, de la América española. En nuestras tierras no existían ni una burguesía ni una clase intelectual que hubiese hecho la crítica de la monarquía absoluta y la Iglesia. Las clases que realizaron la independencia no podían implantar las ideas democráticas y liberales porque no había ningún lazo orgánico entre ellas y esas ideas"13. La realidad de Hispanoamérica exigía de los líderes de la independencia una dosis de creatividad política que permitiera reelaborar y recrear los idcales libcrales y democráticos. En lugar de ello, "prefirieron apropiarse de la lilosolía política de los franceses, de los ingleses y de los norteamericanos. Era natural que los hispanoamericanos procuraran hacer suyas esas ideas y que quisieran implantarlas en nuestros países: esas ideas eran las de la modernidad naciente. Pero no bastaba con adoptarlas para ser modernos: había que adaptar-

1.3(). Ibid.

1.31. Ibid.

1.32. Ihid.

133. Ibicl. p. 64

1.34. O. Paz. Sor Iucina Inés.... p. 29 
las. La ideología republicana y democrática liberal fue una superposición histórica. No cambió a nuestras sociedades pero sí delormó las conciencias: introdujo la mala fe y la mentira en la vida política"|?

b) Modernidad. El problema general de la modernidad fue algo que ocupó la alención de Octavio Paz, como ya vimos en la primera sección de este ensayo. También llamó su atención el problema específico de la modernidad latinoamericana o, más concretamente, la búsqueda de modernidad en la que se vieron empeñadas las élites latinoamericanas una vez que se logró la independencia de España. La mejor manifestación de estas ansias de modernidad fueron las constiluciones democrático-liberales que se proclamaron inmediatamente después de la independencia. Inspiradas en las constituciones europeas y norteamericana "sólo servían para vestir a la moderna las supervivencias del sistema colonial"136. Movimientos políticos e intelectuales posteriores a la independencia y que recorren el siglo XX - la reforma liberal y el positivismo (desde el último tercio del siglo XIX), las revueltas populares que se inician con la revolución mexicana y culminan con la crisis de 1929-30, el nacionalismo revolucionario de Lázaro Cárdenas, Haya de la Torre y Perón, la revolución cubana, el modelo neoliberal-, todos estos movimientos han tenido como uno de sus empeños traer la modernidad a América Latina -incluso cuando ese proyecto de modernidad se inspiró en los ideales socialistas, hijos también de la Edad Moderna.

La tan ansiada modernidad no llegó o llegó incompleta. Y ello porque, en opinión de Paz, en América Latina han faltado los supuestos culturales - cientílicos, lilosóficos, literarios y políticos-que en Europa dieron vida al proyecto de la modernidad. Sobre todo, faltó la filosofía crítica, es decir, ese ímpetu desacralizador cle divinidades e instituciones que animó a los ilustrados del siglo de las luces. "Aunque no tuvimos un Descartes ni nada parecido a lo que se ha llamado la 'revolución científica', me parece que lo nos faltó sobre todo fue el equivalente de la Ilustración y de la filosofía crítica. No tuvimos siglo XVII: ni con la mejor buena voluntad podemos comparar a Feijoo o a Jovellanos con Hume, Locke, Diderot, Rousseau, Kant. Allí está la gran ruptura: allí donde comienza la era moderna, comienza también nuestra separación... Como no tuvimos Ilustración ni revolución burguesa - ni Crítica ni Guillotina - tampoco tuvimos esa reacción pasional y espiritual contra la Crítica y sus construcciones que fue el romanticismo"|37.

Para los latinoamericanos, pues, la modernidad ha sido "nuestra diosa y nuestro clemonio"13x. Ha habido diversas tentativas de modernizacion social, económica y política, pero todas ellas se han tenido que enfrentar con el lastre del pasado

1.35. Ibid.. pp. 29-30

136. O. Paz. El laberinto de la soledad..., p. 133

137. O. Paz, "Literatura y crítica". En Fundación y disidencia..., p. 62

1.38. O. Paz, "La búsqueda del presente". En Fundación y disidencia..., p.. 36 
colonial y de la herencia española. A diferencia de Estados Unidos, que "nacieron con la modernidad", "nosotros nacimos en el momento en que España y Portugal se apartaban de la modernidad. De ahí que a veces se hablase de 'europeizar' a nuestros países: lo modemo estaba fuera y teníamos que importarlo"|?3." Muchas veces, esa "importación" supuso una renuncia al pasado, una abolición brutal de todo lo que pudiera recordar la época de la barbarie; otras, como sucedió en México, "la búsqueda de la modernidad nos llevó a descubrir nuestra antigüedad, el rostro oculto de la nación"|4(1). En todo caso, la búsqueda frustrada de la modernidad latinoamericana, desde la independencia hasta nuestros días, enseña una lección: "entre tradición y modernidad hay un puente. Aisladas, las tradiciones se petrifican y las modernidades se volatilizan; en conjunción, una anima a la otra y la otra le responde dándole peso y gravedad"/4!.

La modernización latinoamericana carga con lastres del pasado colonial que, a lo largo de su historia posindependentista, la han marcado de forma indeleble. El primero de esos lastres es la ideología, entendida como una deformación de la realidad: "con nosotros las ideas tuvieron la función de máscaras; así, se convirtieron en una ideología... la ideología convierte las ideas en máscaras: ocultan al sujeto y, al mismo tiempo, no lo dejan ver la realidad. Engañan a los otros y nos engañan a nosotros mismos" 142 . Segundo, los caudillos, que "inventaron países que no eran viables ni en lo político ni en lo económico y que, además, carecían de verdadera fisonomía nacional" 14 ? . Tercero, la dispersión, las guerras civiles .) las dictaduras, que reprodujeron la herencia hispanoárabe, "con sus jeques revoltosos" y el afán de conquista de los territorios liberados ${ }^{144}$. Cuarto, las oligarquías que, "incapaces de gobernar en nombre propio"|45, se ampararon para ello en el poder militar y la Iglesia. Quinto, el patrimonialismo, mediante el cual quienes ocupan cargos de alto nivel político dirigen al Estado y a la nación "como una extensión de su patrimonio particular, esto es, como si fuesen su casa"146. Por último, la violencia, puesto que "en países sin experiencia democrática, con oligarquías ricas y gobiernos pobres, la lucha entre las facciones políticas desemboca fatalmente en la violencia... la guerra civil endémica produjo el militarismo y el militarismo a las dictaduras"/47.

De los vicios anteriormente señalados, quizás el que más se ha fijado en las sociedades latinoamericanas ha sido el patrimonialismo - con sus vetas de co-

139. Ibíd.

140. Ibíd.

141. Ibid., p. 37

142. O. Paz, "América Latina y la democracia". En Ideas y costumbres I..., p. 79

143. Ibíd.

144. Ibid.

145. Ibid.

146. Ibicl.

147. Ibid., p. 80 
rrupcıón, favoritismo y arbitrariedad. En la segunda mitad del siglo XX, dice Paz, la situación se volvió más grave, pues los vicios del patrimonialismo se combinaron con dos "supersticiones pseudo modernas: el estatismo y el populismo. El estatismo pretende corregir los excesos y fallas del mercado pero no ha logrado sino paralizar nuestras economías, hundidas bajo el peso de enormes, incompetentes y ávidas burocracias. El populismo ha derrochado el tesoro público y ha empobrecido a aquellos que intentaba beneliciar y proteger: los desposeídos... el estatismo latinoamericano no ha sido sino la resurrección del viejo patrimonialismo colonial. Desenmascararlo es parte de esa gran tarea de higiene política que han cmprendido algunos latinoamericanos"'/4x.

c) Excentricidad latinoamericana. Una de las ideas más lúcidas de Paz es la que consiste en entender a América Latina como una "excentricidad" de Europa, lo cual tiene que ver con la también excentricidad de España con relación a Europa — situación compartida por Estados Unidos y Inglaterra respecto del Continente. América Latina fue colonizada por españoles y portugueses, hijos de la Contrarreforma y de las cruzadas; Estados Unidos por ingleses, hijos de la Reforma protestante. "Unos y otros comenzamos por ser una proyección europea. Ellos de una isla y nosotros de una península. Dos regiones excéntricas por la geografía, la historia y la cultura. Ellos vienen de Inglaterra y la reforma; nosotros de España, Portugal y la Contrarreforma. Apenas debo mencionar, en el caso de los hispanoamericanos, lo que distingue a España de otras naciones europeas y lc otorga una notable y original fisonomía histórica. España no es menos excéntrica que Inglaterra aunque lo es de manera distinta. La excentricidad inglesa es insular y se caracteriza por el aislamiento: una excentricidad por exclusión. La hispana es peninsular y consiste en la coexistencia de diferentes civilizaciones y pasados: una excentricidad por inclusión"14\%.

El carácter de la colonización realizada por ingleses y españoles expresa bien los talantes históricos y culturales de cada una de esas excentricidades que fueron Inglaterra y España. Los primeros quisieron crear comunidades religiosas no contaminadas por el paganismo, es decir, comunidades cerradas, semcjantes a las que existían en su país de origen. De aquí el rechazo a las poblaciones nativas americanas. Los segundos querían extender los dominios del catolicismo, convirlicndo a los infieles, tal como había sucedido en las guerras contra los árabes. "Las colonias inglesas en América fueron creadas por grupos de colonos inspirados por motivos religiosos, políticos y económicos... los ingleses quisieron lundar comunidades a imagen y semejanza de las que existían en la madre patria... muchos de esos colonos cran disidentes religiosos. De ahí la doble influencia de la religión y la utopía en la formación de la democracia política de los Estados

148. O. Paz, "Alba de la libertad". En Ideas y copstumbres I.... p. 470)

149. O. Paz. "La búsqueda del presente". En Fundación y disidencia..., p. 3.3

\section{4}

Realidad 80, 2001 
Unidos... Entre los españoles aparecen también los motivos religiosos pero en lanto que los ingleses fundaron sus comunidades para escapar de la ortodoxia, los españoles las establecieron para extenderlas. En un caso, el principio fundador fue la libertad religiosa; en el otro, la conversión de los nativos sometidos a una ortodoxia y a una Iglesia"|50.

Unos defendían la libertad religiosa; los otros le apostaban a la evangelización. Los primeros establecieron comunidades separadas de los habitantes nativos; los segundos trataron de integrarlos religiosa y lingüísticamente en el orden que se veían Ilamados a establecer. Estados Unidos terminó por ser el lugar de nacimiento de una de las vertientes de la democracia moderna - la centrada en la delensa de los derechos individuales-, mientras que América Latina terminó por convertirse en un lugar propicio para el surgimiento de dictaduras militares del más diverso signo. Una de las razones de ellos quizás sea que "los norteamericanos nacieron con la Reforma y la Ilustración, es decir, con el mundo moderno; nosolros con la Contrarreforma y la Neoescolástica, es decir, contra el mundo moderno"1s!.

Asimismo, los Estados Unidos dieron continuidad a la excentricidad inglesa —una excentricidad por exclusión — siendo fundados como un proyecto anclado no en el pasado, sino con la mirada puesta en el futuro. "Los Estados Unidos lucron fundados. a la inversa del resto de naciones, no en respuesta a un pasado común. una tradición, sino por una visión del futuro. Fueron fundados por un mesianismo singular: en contra de la historia. Para los puritanos la historia signilicaba la herencia romana que pervirtió al cristianismo primitivo; para los "padres fundadores". Ios privilegios y las injusticias de la sociedad jerárquica... La utopía se convirtió en lo que hoy son los Estados Unidos: un imperio democrático. cs decir, una realidad social con todos los defectos y cualidades de lo que pertenece a la historia"

América Latina, por su parte, lue expresión multiplicada de la excentricidad cspañolals - una excentricidad por inclusión. El proyecto de los colonizadores españoles se edifícó sobre la herencia del pasado, un pasado que no siempre se arlicula armónicamente con el nuevo orden. Fue un espejo invertido de lo sucedido en Estados Unidos ${ }^{154}$. Además, integración del pasado en el orden colonial (hacia el siglo XVII) estuvo guiado por una "política de puente": "establecer una vía de comunicación. más sobrenatural que natural, entre el mundo indígena

1.5(). O. Paz. Sor .Jucuna Inés.... p. 29

1.5I. O. Paz, "América Latina y la democracia". En Icleas y: costumbres I.... p. 76

1.52.Ibicl. p. 1.55

153. O. Paz, "La búsqueda del presente". En Fundación y disidencia ... p. 33

154. O. Paz, "América Latina y la democracia". En Ideas y" costumbres. I.... p. 142 
y el cristiano"1.5., dando lugar a un sincretismo animado por la búsqueda de prefiguraciones y signos del cristianismo en el paganismo prehispánico ${ }^{156}$.

\section{Reflexión final}

Obviamente, el recorrido que hemos efectuado en torno al pensamiento de Octavio Paz deja cosas importantes fuera de su consideración. Aquí sólo buscábamos una aproximación a algunas de sus ideas fundamentales, con la intención expresa de animar a quienes no conocen el pensamiento de $\mathrm{Paz}$ para que se internen en el mismo y enriquezcan su propio horizonte vital y espiritual.

Después de este recorrido, algunas cosas se imponen con contundencia. La primera, la variedad de ámbitos de la realidad histórica, política y cultural que merecieron la atención del mexicano. Pero no sólo eso: también destaca la profundidad con la que abordó cada uno de los temas y problemas que lo ocuparon a lo largo de su trayectoria intelectual. Tuvo una indudable erudición; pero también tuvo, a la vez, lucidez y creatividad no sólo para plantearse inquietudes de fondo, sino para hacer que el lector también meditara sobre ellas y llegara a sus propias conclusiones, por lo demás siempre provisionales.

Lo anterior lleva a una segunda conclusión; ésta tiene que ver con la experiencia de leer a Paz. Más que leerlo, a Paz hay que interpelarlo, luego de ser interpelados por él. Y es que el ejercicio de leer a Paz más que de lectura es un ejercicio de diálogo, un diálogo cautivador que se vuelve más interesante ahí cuando el autor invita al lector a reflexionar sobre los grandes misterios de la realidad humana: la muerte, la sexualidad, el amor, lo sagrado. Con maestría, Paz desafía a quien lee sus escritos a pensarse de nuevo, a pensarse ante los otros y con los otros. Su lectura es un desafío a atreverse a traspasar hacia la "otra orilla", ahí donde está ese misterio que es el Otro y lo Otro.

Por último, con Paz el idioma español muestra todas sus posibilidades estéticas, filosóficas y religiosas. Quienes han pensado que el español es un idioma pobre, que no da para hablar de cosas importantes, Paz les hace ver lo equivocados que están. Por supuesto, su uso del español ni implica un provincianismo trasnochado - lo sabe parte de la herencia europea - ni un desconocimiento o rechazo de otros idiomas tan relevantes como el español para hablar de cosas profundas. Dos de los idiomas que más frecuentó y con los cuales dijo cosas importantes fueron el francés y el inglés. También tradujo poemas del japonés, así como textos indios, al español.

En definitiva, Paz es uno de esos intelectuales latinoamericanos cuya trayectoria siguió los pasos de esas grandes figuras intelectuales que, de José Martí a

155. O. Paz, Sor Juana Inés.... p. 55

156. Ibicl. pp. 55-56 
Alfonso Reyes, se destacaron no sólo por la vastedad de su obra intelectual, sino también por la preocupación por los problemas de su tiempo. Su obra quiso ser una respuesta a esos problemas; una respuesta que, más allá de ser un intento por of recer una luz en torno a situaciones concretas, estaba animada por un propósito más ambicioso: ayudar a los hombres a ser un poco mejores de lo que son. Al final de su "Itinerario", Paz dice algo que resume bien el propósito de su vida: "el mal es humano, exclusivamente humano. Pero no todo es maldad en el hombre. El nido del mal está en su conciencia, en su libertad. En ella está también el remedio, la respuesta contra el mal. Esta es la única lección que yo puedo deducir de este largo y sinuoso itinerario: luchar contra el mal es luchar contra nosotros mismos. Y ese es el sentido de la historia".

San Salvador, 20 de noviembre de 2000 